Western University

Scholarship@Western

Brain and Mind Institute Researchers'

Publications

Brain and Mind Institute

8-1-2012

\title{
Gonadotropin-releasing hormone plasticity: a comparative perspective.
}

\author{
T J Stevenson \\ Institute for Mind and Biology, University of Chicago, Chicago, IL 60637, United States \\ T P Hahn \\ Department of Neurobiology, Physiology, and Behavior, University of California, Davis, United States \\ S A MacDougall-Shackleton \\ Department of Psychology, Advanced Facility for Avian Research, University of Western Ontario, Canada \\ G F Ball \\ Department of Psychological and Brain Sciences, Johns Hopkins University, United States
}

Follow this and additional works at: https://ir.lib.uwo.ca/brainpub

Part of the Neurosciences Commons, and the Psychology Commons

\section{Citation of this paper:}

Stevenson, T J; Hahn, T P; MacDougall-Shackleton, S A; and Ball, G F, "Gonadotropin-releasing hormone plasticity: a comparative perspective." (2012). Brain and Mind Institute Researchers' Publications. 273.

https://ir.lib.uwo.ca/brainpub/273 
Review

\title{
Gonadotropin-releasing hormone plasticity: A comparative perspective
}

\author{
T.J. Stevenson ${ }^{\text {a,*}}$, T.P. Hahn ${ }^{\text {b }}$, S.A. MacDougall-Shackleton ${ }^{\text {c }}$, G.F. Ball ${ }^{\mathrm{d}}$ \\ a Institute for Mind and Biology, University of Chicago, Chicago, IL 60637, United States \\ ${ }^{\mathrm{b}}$ Department of Neurobiology, Physiology, and Behavior, University of California, Davis, United States \\ ${ }^{\mathrm{c}}$ Department of Psychology, Advanced Facility for Avian Research, University of Western Ontario, Canada \\ ${ }^{\mathrm{d}}$ Department of Psychological and Brain Sciences, Johns Hopkins University, United States
}

\section{A R T I C L E I N F O}

\section{Article history:}

Available online 3 October 2012

\section{Keywords:}

GnRH1

Reproduction

LHRH

Gonadotropins

Vertebrate

Kisspeptin

LH surge

Feedback

\begin{abstract}
A B S T R A C T
Gonadotropin-releasing hormone 1 (GnRH1) is a key regulator of the reproductive neuroendocrine system in vertebrates. Recent developments have suggested that GnRH1 neurons exhibit far greater plasticity at the cellular and molecular levels than previously thought. Furthermore, there is growing evidence that sub-populations of GnRH1 neurons in the preoptic area are highly responsive to specific environmental and hormonal conditions. In this paper we discuss findings that reveal large variation in GnRH1 mRNA and protein expression that are regulated by social cues, photoperiod, and hormonal feedback. We draw upon studies using histochemistry and immediate early genes (e.g., c-FOS/ZENK) to illustrate that specific groups of GnRH1 neurons are topographically organized. Based on data from diverse vertebrate species, we suggest that GnRH1 expression within individuals is temporally dynamic and this plasticity may be evolutionarily conserved. We suggest that the plasticity observed in other neuropeptide systems (i.e. kisspeptin) may have evolved in a similar manner.
\end{abstract}

(c) 2012 Elsevier Inc. All rights reserved.

\section{Introduction}

In vertebrates, hypothalamic peptides are a critical component of the neuroendocrine regulation of reproduction. The identification of a single decapeptide in sheep and swine called Gonadotropin-releasing hormone (GnRH1) that exerts specific and profound effects on pituitary release of gonadotropins provided a significant advancement for understanding how the brain controls reproduction (Burgus et al., 1972; Schally et al., 1971). Several subsequent studies identified GnRH1 in a wide range of species suggesting it is an evolutionarily conserved decapeptide that connects the brain functionally with the peripheral reproductive system (Gorbman and Sower, 2003; King and Millar, 1992; Muske, 1993; Okubo and Nagahama, 2008; Roch et al., 2011; Somoza et al., 2002). In the vast majority of species, the GnRH1 neuronal system is the final common processing step for the control of gonadotropin secretion and is essential for fertility and the successful timing of reproduction. GnRH1 neuronal plasticity can take many forms. One aspect of this phenomenon relates to the electrical and cellular events involved in the episodic secretion of GnRH1 (Herbison, 1998; Jasoni et al., 2010; Moenter et al., 2003) as well as the cell-cell communication processes (Prevot et al., 2010) that underlie the role of $\mathrm{GnRH1}$ in reproductive function. However, GnRH1 plasticity is also manifested at the level of mRNA and protein expression in

\footnotetext{
* Corresponding author.

E-mail address: tjsteven@uchicago.edu (T.J. Stevenson).
}

response to external and internal signals and that is the focus of the current paper. In this review, we will discuss the photoperiodic, social, and hormonal regulation of GnRH1 mRNA and protein expression from a comparative perspective.

\subsection{GnRH1 structure, distribution and function}

To date, at least two isoforms of the GnRH decapeptide have been identified in all species. These are (1) the hypophysiotropic GnRH1 located in the anterior hypothalamus/preoptic area (AHPOA), referred to as GnRH1, and (2) other GnRH peptides found in other regions of the brain (Fernald and White, 1999; Gore et al., 2002; King and Millar, 1992; Okuzawa et al., 1990; Zohar et al., 2010). Among these other GnRH populations, GnRH2 is primarily located in the midbrain, and GnRH3 is predominantly localized in the olfactory and forebrain regions (Fernald and White, 1999; Zohar et al., 2010). In the vast majority of species, GnRH1 cells are surprisingly few in number, ranging from 800 to 1000 neurons primarily distributed in a loose continuum from the anterior hypothalamus/ preoptic area into the septum (Fig. 1A, Silverman et al., 1994). GnRH1 cells generally exhibit an ovate, fusiform or round morphology with either one (i.e. unipolar) or two (i.e. bipolar) projections (Lehman and Silverman, 1988; Lehman et al., 1988). Most GnRH1 cells have been shown to project via a hypothalamo-infundibular tract to the median eminence (ME) enabling the release of the decapeptide into the hypothalamo-pituitary portal system (Fig. 1B Barry, 1979; Prevot et al., 2010). Recently, another group of GnRH1 
A

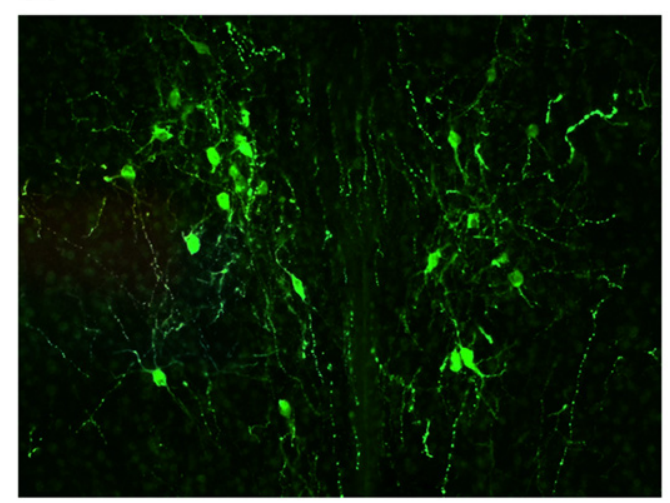

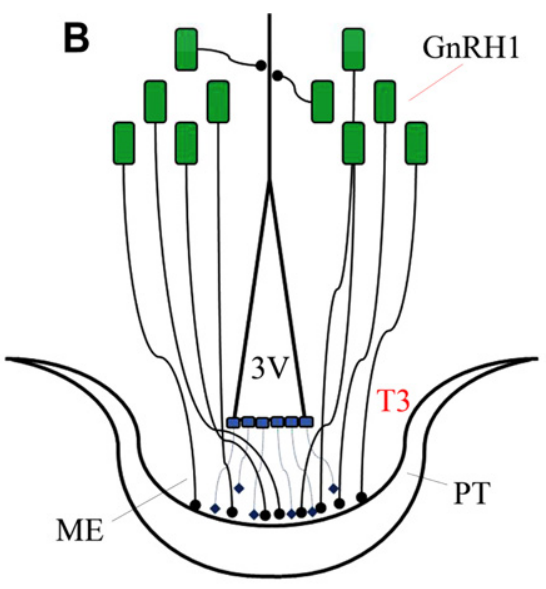
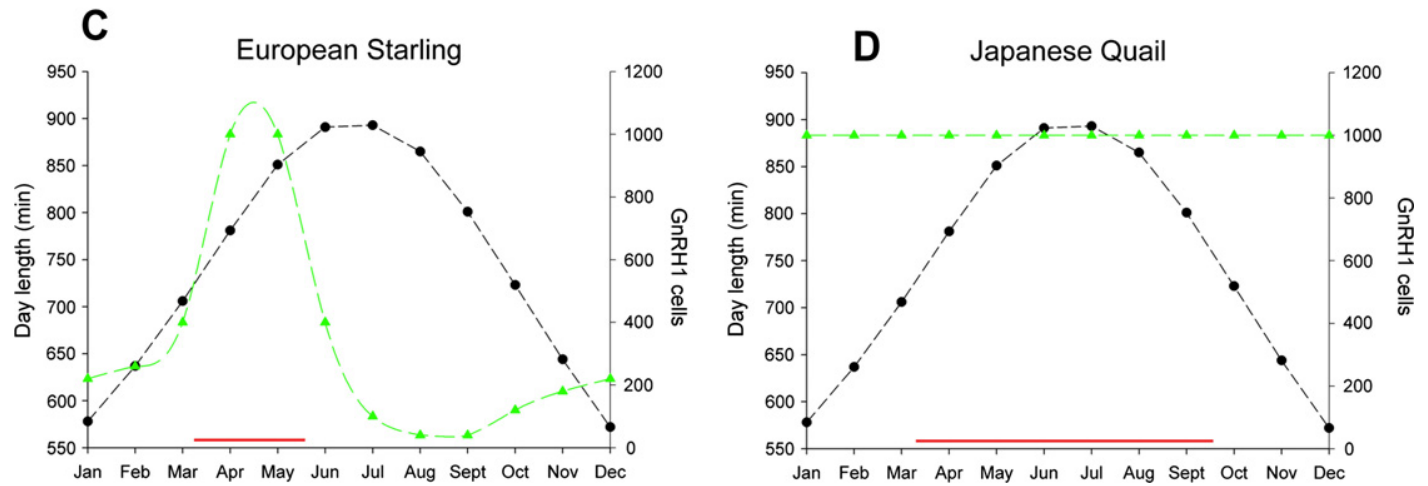

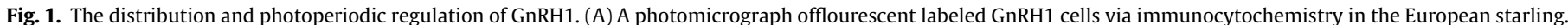

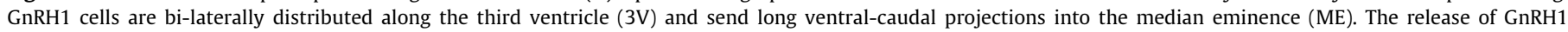

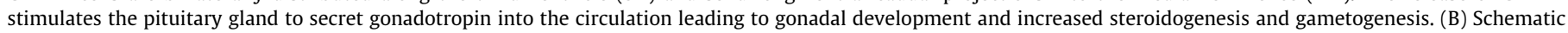

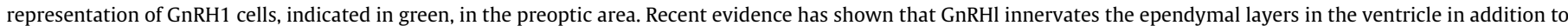

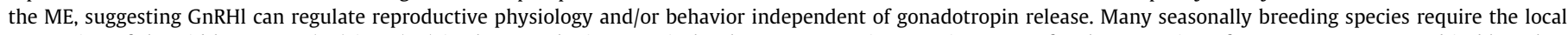

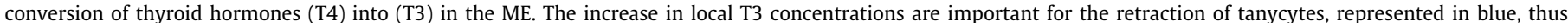

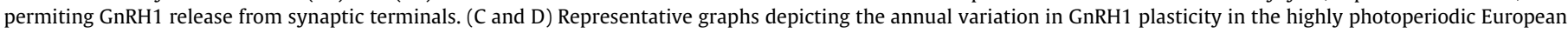

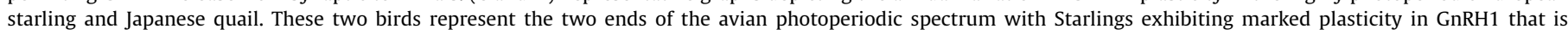

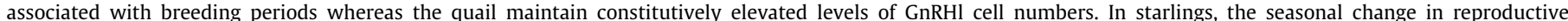

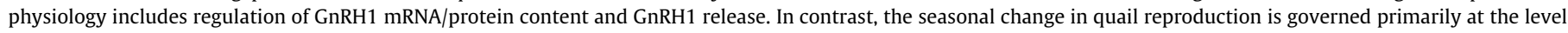
of GnRH1 release. The red bar indicates the breeding period.

cells was found to project into the organum vasculosum of the lamina terminalis (OVLT) and terminate outside the blood-brain-barrier (Herde et al., 2011). This cell group is proposed to secrete GnRH1 directly into the ventricle and may be involved in the LH surge in mammals (Herde et al., 2011). GnRH1 has also been implicated in direct regulation of sexual behavior independent of gonadotropin release (Cheng, 1977; Maney et al., 1997; Moss and McCann, 1973; Pfaff, 1973). This observation has led to the hypothesis that GnRH1 may be acting in brain regions other than the septo-infundibular system to coordinate changes in reproductive physiology with sexual behavior.

\subsection{Discovery of GnRH1 plasticity in birds}

In this section we will describe the marked plasticity in GnRH1 that was discovered in birds in the 1980s. This is a form of neuroplasticity that has not been widely recognized. The term neuroplasticity is evoked to describe a range of phenomena in the brain. One of the major developments in the field of neuroscience in the late 20th century was to recognize that significant morphological and physiological brain plasticity occurred quite frequently in adult endothermic vertebrates. Physiological plasticity generally refers to enduring changes in synaptic physiology that can occur after different patterns of physiological stimulation. Long-term potentiation (LTP) and long-term depression (LTD) are two well-known examples of this phenomenon (Bear and Malenka, 1994; Malenka and Bear, 2004). Morphological plasticity refers to measurable changes in morphology including cell size, cell number, cell shape and the connectivity among brain nuclei. This review will focus on plasticity in GnRH1 mRNA and protein in a variety of species.

The lack of substantial behavioral recovery after brain damage produced by accidental trauma or neurodegenerative diseases was, for a long time, taken as evidence for the absence of marked plasticity in the adult central nervous system of many vertebrate species including humans. It has, however, been acknowledged during the last few decades that mature adult neurons in the adult mammalian brain change their size and anatomical relationships with adjacent glial cells or reorganize their dendritic tree over the course of hours to days (e.g., Garcia-Segura et al., 1988; Theodosis and Poulain, 1992). While neurogenesis was previously thought to be completely absent in adult endothermic vertebrates, a limited amount of neurogenesis has been identified in specific brain regions of adult mammals (Altman and Das, 1965; Altman, 1969; Gould, 2007), possibly including humans (Bhardwaj et al., 2006; Eriksson et al., 1998). Neurogenesis and neural plasticity are, to an even greater extent, also observed in birds as well as other species and several aspects of this plasticity seem to be related to the prominent annual cycles of gonadal activity. For example the forebrain nuclei that regulate vocal production in songbirds exhibit marked changes 
in morphology and physiology (Ball et al., 2002; Brenowitz, 2004) and similar seasonal changes have been observed in other species (Tramontin and Brenowitz, 2000).

In mammals, GnRH1 mRNA and protein levels increase during reproductive development (i.e., puberty) and then reach a plateau in adulthood (Gore et al., 1999; Wolfe et al., 1996). Few vertebrate species are known to exhibit GnRH1 plasticity in adulthood and the degree of morphological plasticity of these cells, if present, is minimal. In contrast to low degree of plasticity in mammals are the marked and reliable changes in GnRH1 expression that was discovered in one avian order, the Passeriformes (Dawson et al., 1985; Foster et al., 1987; see (Ball and Hahn, 1997) for a review of this early work). The initial study demonstrated that European starlings (Sturnus vulgaris) exhibited significant variation in GnRH1 protein content in the hypothalamus across breeding and non-breeding states (Dawson et al., 1985). These findings led to the investigation of a number of other related species that also exhibit a similar pattern of GnRH1 expression, with approximately a 100-fold difference between the high concentrations observed in breeding as compared to those measured in non-breeding birds (Dawson et al., 2002). However, not all species investigated have exhibited such marked variation in GnRH1 brain content. The degree of GnRH1-system plasticity observed among passeriformes is proposed to have evolved as an adaptation that facilitates the timing of a diverse set of reproductive schedules that exhibit a range of flexibility (MacDougall-Shackleton et al., 2009). In birds that are highly photoperiodic and have restricted breeding periods, the degree of GnRH1 plasticity is more pronounced than in flexibly or opportunistically breeding species. Opportunistic species are those that seem to be able to breed whenever conditions are favorable for reproduction. So species such as crossbills (genus Loxia) will breed in the winter under short day conditions if sufficient numbers of conifer cones with nutrient rich seeds are available (Hahn, 1995). Information theoretic approaches including the constancy/contingency model (Colwell, 1974) predict GnRH1 plasticity in relation to a variety of reproductive schedules (Stevenson and Ball, 2011). In the next section, we focus on the environmental and hormonal regulation of GnRH1 using select examples from different vertebrate species.

\section{Environmental and hormonal regulation of GnRH1 expression}

The GnRH1 expressing cells in the brain of vertebrates are an evolutionarily conserved neural system that provides a key link between the brain and peripheral reproductive endocrine system (Herbison et al., 2006). There are other neuroendocrine pathways that play a role in some circumstances in the regulation of reproductive outcomes (e.g., thyroid hormones, prolactin, glucocorticoids), however, the output of the GnRH1 cells clearly regulates the reproductive cycle and acts as a master and commander for the timing of reproduction. The critical event that regulates the onset of reproduction is ovulation or oviposition (Ball, 1993). The final physiological step for ovulation is the surge of luteinizing hormone that is mediated by positive feedback on the GnRH1 neuronal system (see Herbison et al. (2006) for a review). Here, we will discuss how the annual change in photoperiod regulates the amount of GnRH1 mRNA and protein expression in birds, how the social environment can modify GnRH1 content in fish, rodents and birds, and then briefly discuss the role of negative feedback by gonadal steroids on GnRH1 plasticity.

\subsection{Photoperiodic regulation of GnRH1 mRNA and protein in birds}

The first identification of marked differences in the hypothalamic content of GnRH1 in birds was in European starlings (Dawson et al., 1985). In birds, the general photoperiodic response consists of marked GnRH1 plasticity that is primarily driven by the annual change in length of the photophase (hereafter day length) (Fig. 1C) as evidenced in European starlings (Dawson, 2003; Dawson et al., 2001; Parry et al., 1997). Here, the vernal increase in day length stimulates the neuroendocrine reproductive system leading to a breeding state termed photostimulated (Dawson et al., 2001). Photostimulation is manifested as gonadal recrudescence, increased gametogenesis, steroidogenesis and high levels of reproductive behaviors. After prolonged exposure to long day lengths, gonadal involution occurs and the neuroendocrine drive for reproduction is 'turned down.' This state is referred to as photorefractory (Dawson and Sharp, 2007; Nicholls et al., 1988). Reproductive photorefractoriness in birds is defined as physiological unresponsiveness to the previously stimulatory long day lengths. This reproductive state is significant as it serves to restrict breeding to periods that are optimal for the developing offspring, and allows birds to undergo other phases of their annual cycle such as molt and premigratory fattening before the onset of inclement weather, even if environmental cues (temperature, food supply, and photoperiod itself) remain favorable. In order to regain physiological responsiveness to the stimulatory long day lengths, many bird species must experience a period of short day lengths associated with the fall and early winter. The exposure to short day lengths is said to 'break' photorefractoriness and leads to a physiological state referred to as photosensitivity (Dawson et al., 2001). This photoperiodic pattern results in birds that transition through three distinct reproductive states: (1) photosensitive (i.e., pre-breeding), (2) photostimulated (i.e., full breeding capability), and (3) photorefractory (i.e., nonbreeding).

Birds that transition through photosensitive, photostimulated and photorefractory states exhibit moderate levels, significantly elevated levels and finally almost undetectable levels of GnRH1, respectively (Dawson et al., 2001; MacDougall-Shackleton et al., 2009). For example, GnRH1 protein expression of laboratory housed European starlings is low while the birds are on short day lengths (Foster et al., 1987; Park et al., 1988; Pinter and Peczely, 2010) but increases following photostimulation with long day lengths (Foster et al., 1987; Park et al., 1988; Pinter and Peczely, 2010). The onset of photorefractoriness after several weeks of exposure to long day lengths results in a dramatic decline in GnRH1 content (Dawson et al., 2001; Foster et al., 1987; Goldsmith et al., 1989; Park et al., 1988). Studies that have investigated GnRH1 content using immunocytochemistry illustrate that the change in GnRH1 protein is associated with a change in the number of detectable immunoreactive cells (Foster et al., 1987; Park et al., 1988; Stevenson and Ball, 2009). In addition to regulating GnRH1 protein content, the release of GnRH1 from synaptic boutons is also regulated by photoperiodic experience (Dawson and Goldsmith, 1997). In photosensitive birds, even though GnRH1 content in the hypothalamus is somewhat elevated, the release of GnRH1 at the median eminence is prevented (Dawson and Goldsmith, 1997). In quail, glial endfeet surround GnRH1 terminals and prevent contact with the basal lamina effectively inhibiting GnRH1 release into the hypothalamo-pituitary portal blood (Yamamura et al., 2004). The vernal increase in day length removes the glial encasement thus permitting GnRH1 secretion leading to gonadal recrudescence (Yamamura et al., 2004). The inhibition of GnRH1 release is then reinstated during the onset of photorefractoriness (Dawson and Goldsmith, 1997; Stevenson et al., 2009a).

Studies that have administered the neuroexcitatory amino acid glutamate analog $\mathrm{N}$-methyl-D-aspartate (NMDA) or $\mathrm{N}$-methyl-DLaspartate (NMA) to birds in different reproductive states have provided valuable insight into dissociating the photoperiodic regulation of hypothalamic GnRH1 content from GnRH1 release. The administration of exogenous NMDA leads to an increase in 
peripheral LH concentrations in a large range of mammals and birds, and therefore, it has been claimed, provides a indicator of the amount of releasable GnRH1 (Brann and Mahesh, 1997; Ebling et al., 1995; Ebling and Cronin, 1998; Meredith et al., 1991; Urbanski, 1990; Strobl et al., 1993). In songbirds, NMDA treatment to photosensitive birds results in large increases in peripheral LH concentrations in the European starling (Dawson, 2005) and Cassin's sparrow (Aimophila cassinii; (Deviche et al., 2008), but only in a moderate increase in photostimulated birds and a negligible change in photorefractory birds. However, white-crowned sparrows (Zonotrichia leucophrys) increase peripheral LH concentrations in response to NMDA regardless of their photoperiodic state (Meddle et al., 1999, 2006b). These data were taken as evidence that the onset of photorefractoriness was associated with the inhibition of GnRH1 release rather than a down-regulation of synthesis. One caveat when comparing the response to NMDA across different studies and therefore, species, is the timing regimen of the injection. In the white-crowned sparrow study, NMDA was administered early in photorefractoriness while sparrows had high GnRH1 cell numbers, suggesting a large pool of GnRH1 content was available for release. Furthermore, the sparrows had gonadal states that suggested the birds had not attained a fully photorefractory state. Thus, the increase in LH release most likely coincided with the early stages of photorefractoriness when $\mathrm{GnRH} 1$ protein is still synthesised but when any decreases in LH release are based on the attenuation of GnRH1 release.

Whether the cellular and molecular mechanisms that are involved in facilitating the release of $\mathrm{GnRH} 1$ during photostimulation are similar to those that prevent the release of $\mathrm{GnRH} 1$ during the onset of photorefractoriness is not well understood. Overall, the findings in starlings suggest that the annual change in day length has a dual role for the regulation of GnRH1 plasticity via (1) GnRH1 synthesis in the POA and (2) GnRH1 release from the ME. Several species in the order Passeriformes have been shown to exhibit dramatic variation in GnRH1 content associated with different reproductive states (Ball and Hahn, 1997; MacDougall-Shackleton et al., 2009). For example, house sparrows (Passer domesticus; Hahn and Ball, 1995; Stevenson and MacDougall-Shackleton, 2005), darkeyed juncos (Junco hyemalis; Deviche et al., 2006; Meddle et al., 2006a,b), house finches (Carpodacus mexicanus; Cho et al., 1998), rufous-collared sparrows (Zonotrichia capensis; [Moore et al., 2006; also see Stevenson et al., 2012]), rufous-winged sparrows (Aimophila carpolis; Small et al., 2008) and American tree sparrows (Spizella arborea; Reinert and Wilson, 1996) exhibit this form of GnRH1 plasticity.

One major gap in this research until recently was an inability to directly measure GnRH1 gene expression across the photoinduced reproductive states. A number of studies attempted to quantify variation in expression of different GnRH1 precursor molecules as an index for GnRH gene transcription by using antibodies directed to the precursor peptide (Moenter et al., 2003; Park et al., 1988; Small et al., 2008). The pro-GnRH-GAP peptide undergoes post-transcriptional processing to produce a 23 amino-acid signal peptide (e.g. pro-GnRH) and a 56 amino-acid GnRH-associated peptide (e.g. GAP). Immunocytochemical studies demonstrated that the amount of pro-GnRH-GAP changes across the photoperiodic states in starlings (Park et al., 1988) and white-crowned sparrows (Moenter et al., 2003). Variation in AH/POA pro-GnRH1-GAP across breeding states was also reported in the rufous-winged sparrow (Small et al., 2008). These data provided evidence indicating that GnRH1 mRNA expression changed with photoperiod as did the active decapeptide, however a persistent inability to sequence the songbird GnRH1 gene hampered direct assessment of this process. The sequencing of the zebra finch (Taeniopygia guttata) genome (Warren et al., 2010) ushered in a new era of avian molecular biology and played a pivotal role in the ability to identify the GnRH1 sequence in passeriformes (Stevenson et al., 2009a; Ubuka et al., 2009). This provided the opportunity to directly assess whether seasonal changes in photoperiod regulate GnRH1 mRNA in a similar manner to protein expression. In starlings moderate levels of GnRH1 mRNA characterize a photosensitive state, and after transferring starlings to long day lengths (photostimulation) there is an increase in mRNA followed by a marked decrease to almost undetectable levels during refractoriness (Stevenson et al., 2009a). An increase in GnRH1 mRNA expressing cells is also observed during reproductive development in another passerine, zebra finches (Ubuka and Bentley, 2009). The change in GnRH1 mRNA levels is primarily a result of alterations in the number of cells expressing GnRH1 (Stevenson et al., 2012, 2009b; Ubuka et al., 2009). It is unlikely that the change in the number of detectable cells occurs as a result of neurogenesis (Stevenson and Ball, 2009). Neurogenesis is widespread in the adult avian brain; however it has not been identified in the preoptic area of the hypothalamus to the extent that would be predicted based on the changes in GnRH1 cell numbers (Nottebohm, 1985, 1989). Photosensitive canaries (Serinus canaria) that are injected with the thymidine analog bromodeoxyuridine (BrdU), a commonly used marker of neurogenesis, and subsequently placed on long day lengths failed to exhibit co-labeling in $\mathrm{GnRH} 1$ cells (unpublished observations, but see (Stevenson and Ball, 2009). The absence of sufficient new neurons in the hypothalamus (Nottebohm, 1985, 1989) combined with the lack of co-localization of BrdU and GnRH1 provides further support that the change in detectable cells is attributed to renewed transcription and translation within existing cells.

\subsection{Social regulation of GnRH1 $m R N A$ and protein in vertebrates}

There is a substantial literature indicating that gonadotropins and steroid hormones are modified by the social milieu an animal experiences (Wingfield and Kenagy, 1991; Wingfield, 1988). There is a growing body of literature illustrating that the GnRH1 system itself is highly sensitive to the social environment (Hoffmann, 2006; Rissman, 1996. Studies in a diverse range of vertebrates, including musk shrews (Suncus murinus; Dellovade and Rissman, 1994), African cichlid fish (Astatotilapia burtoni; (Burmeister et al., 2007; Maruska et al., 2010; White et al., 2002; White and Fernald, 1993) and green treefrogs (Hyla cinerea; Burmeister and Wilczynski, 2005) have shown that GnRH1 expression is highly dynamic and may be a driving force for reproductive and behavioral plasticity. One of the best-studied models for GnRH1 plasticity is the cichlid fish $A$. burtoni. In this species, males exhibit very different phenotypic morphs that are dependent on their social status (Fernald and Hirata, 1977; Hoffmann, 2006). Territorial males are larger, engage in mating behavior at higher rates and have larger GnRH1 cells and more mRNA compared to non-territorial males (Burmeister et al., 2007; White et al., 2002). The greater levels of GnRH1 mRNA and cell size cannot be attributed to higher level of testosterone as castration in this species further increases GnRH cell size in territorial males, likely by removing negative feedback (Francis et al., 1992). Recently, a time course study that evaluated the change in gene expression profiles during "social ascent," the opportunity for non-territorial males to develop into territorial males, was associated with a rapid increase in GnRH1 mRNA levels ultimately reaching territorial male levels within $2 \mathrm{~h}$ (Maruska et al., 2010). This rapid increase in GnRH1 mRNA expression suggests direct neural input from sensory modalities rather than steroid hormone effects, providing a unique opportunity to investigate how different social cues can regulate GnRH1 plasticity.

In birds, there has been a long-standing interest in how visual and auditory cues are integrated leading to the increase in gonadotropin secretion (Ball, 1993; Ball and Ketterson, 2008; Hinde, 1965; Lehrman, 1965). Recently, it was shown in male ring doves 
(Streptopelia risoria) that the number of cells expressing GnRH1 mRNA and protein increases significantly after exposure to a receptive female (Mantei et al., 2008). In starlings, the presence of a female significantly facilitated the photoinduced increase in $\mathrm{GnRH} 1$ cells in photostimulated male starlings (Stevenson and Ball, 2009). Together these data suggest that female presence will increase GnRH1 cell numbers in birds. However, female birds have not shown the same degree of GnRH1 plasticity, suggesting a possible sex difference in the ability of social cues to affect this neuronal system. Specifically, female house sparrows paired with males did not exhibit different GnRH1 cell numbers (Stevenson et al., 2008). Furthermore, when female white-throated sparrows are presented with male songs, the numbers of GnRH1 immunoreactive cells did not vary, nor was there a significant difference in the induction of the immediate early gene Egr-1 in GnRH1 cells (Maney et al., 2007). Instead, the male song activated an increase in Egr-1 expression in the medio-basal hypothalamus, a region implicated in regulating the release of GnRH1 from synaptic boutons. Indeed male and female birds process environmental stimuli differently (Ball and Ketterson, 2008). For example, females require more access to supplementary cues such as those provided by a mate or aspects of the physical environment to attain full reproductive development whereas males will reach full reproductive maturation in response to stimulatory day lengths (Ball and Ketterson, 2008; Silver, 1978). One example of such an effect has been shown in female white-winged crossbills (Loxia leucoptera). White-winged crossbills are an opportunistically breeding species and rely on the presence of food cues to successfully time the breeding period (MacDougall-Shackleton et al., 2001). In this species, captive males held on thermally neutral temperature with unlimited food show little or no seasonal GnRH1 plasticity, but instead a constitutively high level of expression, even when gonads collapse on declining photoperiod in autumn, presumably to maintain physiological responsiveness to unpredictable food resources (i.e. seeds). The presence of significant GnRH1 plasticity in captivity is only observed in females and not males, with an increase in the number of cells occurring during the breeding season (MacDougall-Shackleton et al., 2001). The current hypothesis is that females require both photoperiodic and supplementary food and/or social cues in order to time egg-laying and this is reflected in the GnRH1 neuronal system. Interestingly, free-living males sampled in interior Alaska, where autumn temperatures dropped to $-30 \mathrm{C}$ during the study period, did show a decline in GnRH protein expression during autumn (Christal et al., 2001) similar in magnitude to that of free-living house finches (see Cho et al., 1998). This indicates that the GnRH1 system even of male crossbills can be down-regulated if conditions (shortening days, declining food supply, and very low ambient temperatures) are sufficiently challenging.

Research on the neural circuitry involved in the integration of different social cues is still in its infancy. Similar to the effects of photoperiodic information on the GnRH1 system, it is unlikely that the change in GnRH1 cell numbers is attributable to the birth and death of neurons. However, there is some evidence to suggest that after brain damage, new GnRH1 cells appear in the POA (Cheng et al., 2011). It is most likely that the midbrain, thalamic and telencephalic brain regions involved in processing auditory and visual cues, for example, provide direct and/or indirect inputs onto the GnRH1 neuronal system (Pfaff et al., 2008; Wilczynski et al., 1993). Evidence for this stems from findings implicating auditory cues acting via midbrain and thalamic auditory regions on the GnRH system in female ring doves (Cheng et al., 1998; Cheng and Peng, 1997). Here the female's own coo has been shown to regulate the GnRH1 system and acts to facilitate copulatory behavior in a 'self-stimulation' manner (Cheng, 1992; Cheng et al., 1988).

Studies of the environmental and social regulation of GnRH1 have generally discussed findings from the perspective of cues hav- ing stimulatory input to the hypothalamo-pituitary-gonad axis. However, there is also evidence that social cues can act to remove inhibitory tone in hypothalamic regions and, therefore, permit the increase in gonadotropin release (Cheng, 1993; Pfaff et al., 2008). In addition to social cues, a number of abiotic cues (e.g. rainfall, temperature and food availability) can affect GnRH1 plasticity. The effect of food availability in white-winged crossbills has already been discussed above. In other flexibly breeding birds, increased rainfall is strongly associated with an increase in GnRH1 immunoreactivity (Deviche et al., 2000; Moore et al., 2006; Small et al., 2007, 2008). The mechanistic basis of how these various abiotic factors regulate GnRH1 plasticity is poorly understood. Future research will face a challenge to untangle the complex neural integration of supplementary cues that involves switches between excitatory and inhibitory inputs from a number of brain regions including midbrain, thalamic, and telencephalic areas.

\subsection{Gonadal steroid regulation of GnRH1 during the reproductive cycle}

It is well documented that gonadal steroids provide negative feedback onto the GnRH1 system in a number of vertebrate species (Herbison et al., 2006). One approach to investigate the negative feedback effects of gonadal steroids on GnRH1 levels is to examine whether the numbers of GnRH1-expressing cells change during the estrous cycle. Studies that employ immunocytochemistry or in situ hybridization have not shown consistent or dramatic changes in GnRH1 content. The few studies that have observed changes in GnRH1 cell numbers revealed small changes (Kobayashi et al., 1978; Silverman et al., 1994; Wray and Hoffman, 1986). In the studies that have identified GnRH1 plasticity, there is a significant increase in the number of GnRH1 cells in the POA between early and late rat proestrus (Rubin and King, 1994). Interestingly, the change in GnRH1 cell numbers occurs in young females, but not in middle aged rats (Rubin and King, 1994). Using in situ hybridization, the numbers of GnRH1 mRNA expressing cells have also been reported to exhibit variation across the rat estrous cycle (Zoeller and Young, 1988). However, other studies report either no change or very little plasticity (Malik et al., 1991; Wiemann et al., 1990).

Another means to assess the effects of steroid hormones on GnRH1 levels is gonadectomy. Here, the removal of the gonads would be predicted to increase GnRH1 cell numbers and hormone replacement would reverse such changes. In rodents, there do not appear to be large or reliable changes in GnRH1 cell numbers following gonadectomy, as determined either via immunocytochemistry (Kelly et al., 1989) or in situ hybridization (Malik et al., 1991; Wiemann et al., 1990; Park et al., 1988; Roberts et al., 1989). In birds, GnRH1 cell numbers in the POA were shown to be highly sensitive to gonadal steroids as castrated starlings exhibited a significant increase in expression (Stevenson and Ball, 2009). In this study, pre-breeding starlings that were castrated and placed on stimulatory day lengths for 2 weeks had more immunoreactive GnRH1 cells compared to intact starlings. Similarly castration increased GnRH1 in territorial, breeding A. burtoni compared to intact individuals (Francis et al., 1992). Taken together, the data suggest that GnRH1 variation in mammals is either muted or absent relative to other vertebrates, and that there are potentially large species differences in GnRH1 plasticity.

In summary, photoperiodic and social cues can have a significant effect on the levels of GnRH1 mRNA and protein expression in birds, fish and mammals. In the vast majority of passeriformes, the annual change in day length drives marked changes in detectable GnRH1 cell numbers. Furthermore, the social context also modulates GnRH1 levels with the general trend for greater cell number or cell size associated with reproductive opportunity. In contrast, gonadal hormone effects on GnRH1 plasticity do not appear to be consistent across vertebrates. Finally, the variation in 
GnRH1 mRNA and protein expression is most likely the result of transcriptional and/or translational modifications and not due to the birth of new neurons.

\section{GnRH1 in the preoptic area exhibits functional topography}

It has been proposed that the vertebrate POA can be divided into distinct anatomical regions based on histochemical and functional attributes (Balthazart and Ball, 2007). Studies that have employed lesions, immediate early gene expression methods (e.g., cFOS, ZENK), as well as immunocytochemistry for specific markers related to the function of hormones or other chemical messengers (e.g., aromatase) have suggested a medial and lateral division, as well as rostro-caudal divisions (Balthazart and Ball, 2007). Here, we highlight data collected in birds and mammals that provide support for the hypothesis of functional topography in the POA with a specific focus on the GnRH1 system.

\subsection{Anatomically localized effects of environmental and hormonal milieu on GnRH1 in birds}

One hypothesis generated from the extensive GnRH1 plasticity in birds focused on whether the variation in GnRH1 expression developed from an overall increase in the number of cells throughout the entire POA or whether discrete regions in the POA are more sensitive to different photoperiodic, social and gonadal states that are known to modulate LH secretion. In order to examine the photoperiodic regulation of $\mathrm{GnRH} 1$ cell number, 3-dimensional plots were created that map the rostral-intermediatecaudal; dorsal-ventral; and medial-lateral location of individual GnRH1 cells within the POA of photosensitive, photostimulated and photorefractory starlings (Fig. 2A). An overall view of the distribution of GnRH1 in the POA shows that the transition from photosensitive to photostimulated and then photorefractory states in male starlings is characterized by a large change in the overall number of cells and it appears that these changes are more apparent in specific regions of the POA. Pre-breeding starlings had moderate levels of GnRH1 mRNA expressing cells predominantly located along the midline, a region corresponding to the medial POA (Stevenson et al., 2009b). After being photostimulated with long day lengths, there was a massive increase in expression in the medialintermediate region and medial-rostral regions (Stevenson et al., 2009b). These data suggest that the development of breeding condition is associated with a selective increase in expression in more rostral GnRH1 cells in the POA. The onset of a non-breeding state revealed that the rostral and intermediate populations of GnRH1 cells significantly declined; the medial-caudal population was the only region that maintained similar cell numbers (Stevenson et al., 2009b). A second follow-up study investigated the temporal pattern of the increase in GnRH1 cell number during the termination of photorefractoriness by short days and the subsequent development of a photosensitive state (Stevenson et al., 2012). Photorefractory female starlings that were transferred to short day lengths exhibit a gradual increase in the number of GnRH1 cells between 10 and 30 days (Stevenson et al., 2012). Moreover, the increase in
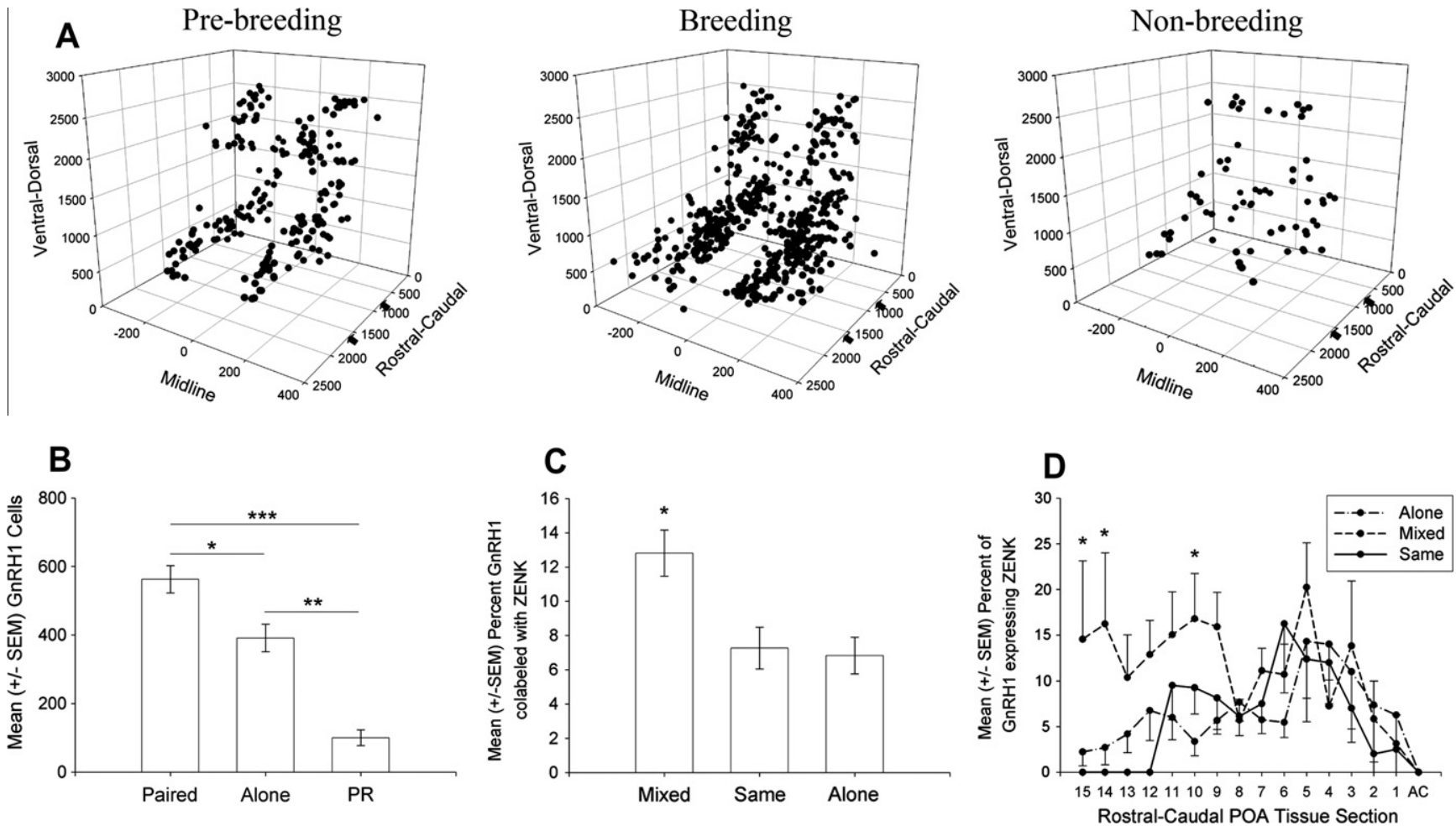

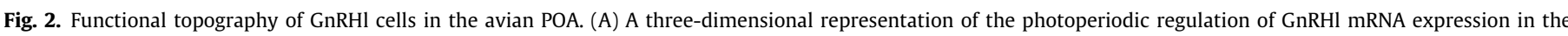

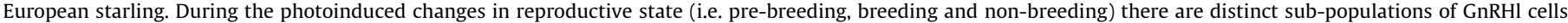

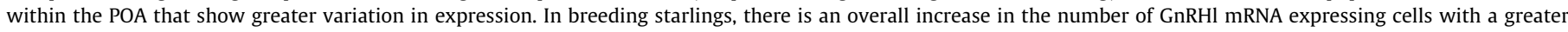

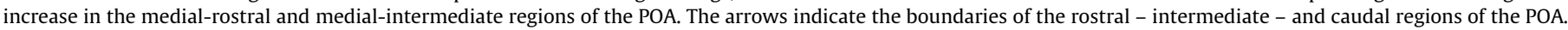

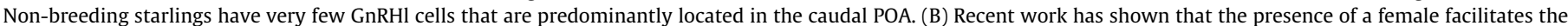

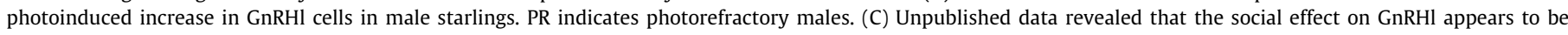

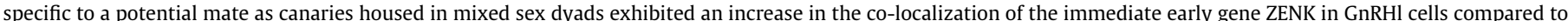

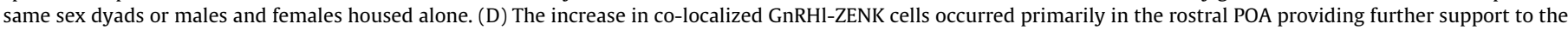
observation of social effects in this region. Data was adapted from Stevenson et al. (2009a,b) and Stevenson and Ball (2009). 
the number of GnRH1 cells occurred primarily in more rostral areas (Stevenson et al., 2012). These data suggested that the termination of photorefractoriness and the development of photosensitivity are associated with the resumption in GnRH1 mRNA expression in a rostral direction within the POA.

In addition to the photoperiodic regulation of $\mathrm{GnRH} 1$, it is well established that the social environment could modulate the photoinduced changes in GnRH1, gonadotropins, gonadal volume, and sex steroid concentrations (Ball and Balthazart, 2002). Again, the observation of marked GnRH1 plasticity in ring doves and European starlings may be based on changes in discrete GnRH1 cells in the POA that are responsive to the social environment. In order to address this question, Stevenson and Ball (2009) plotted the rostral-caudal distribution of GnRH1 cells and compared the numbers of cells in each tissue section in photostimulated males paired with a female, photostimulated males housed alone, and photorefractory males housed alone. Males that were paired with a female displayed a significant increase in the number of GnRH1 immunoreactive cells in the rostral region in the POA. The POA is a key site for the regulation of reproductive behavior in a wide range of vertebrate species. Indeed specific regions have been proposed to regulate different components of reproductive behavior, for example, appetitive and consummatory sexual behaviors (Ball and Balthazart, 2004; Panzica et al., 1996). The rostral POA has also been shown to exhibit an increase in immediate early gene activation after male starlings engage in song (Riters et al., 2004) and after Japanese quail (Coturnix coturnix) engage in appetitive sexual behaviors (Taziaux et al., 2006). Furthermore, lesions that target specific subregions in the POA have supported the existence of a topographic organization in starlings (Riters and Ball, 1999) and quail (Balthazart et al., 1998). In combination, these data suggest that the rostral POA is highly sensitive to the social environment and may play a role in regulating behavioral interactions with a conspecific.

One way to test whether the GnRH1 cells in the rostral POA are linked to social interactions is to ask whether these rostral populations of GnRH1 cells co-express the immediate early gene ZENK during behavioral interactions. Unpublished results in male and female canaries suggest that when birds are paired in male-female dyads, there is a significant increase in the percentage of GnRH1 cells that are co-labeled with the ZENK, compared to same sexdyads or birds housed alone (Fig. 2C; unpublished observation). Thus, immediate early gene activation in GnRH1 cells may be dependent on the presence of a potential mate and not simply the presence of another conspecific. Furthermore, the induction of ZENK in GnRH1 cells was primarily located in the rostral POA (Fig. 2D). Together, these data support the hypothesis that the GnRH1 system is highly dynamic and that specific sub-populations are more sensitive to the social environment and may play a critical role during behavioral interactions with a potential mate. How social cues are integrated and what neural and hormonal inputs drive the changes in GnRH1 plasticity is not well understood. Further work that examines localization of GnRH1 plasticity in male African cichlids $A$. burtoni, male green treefrogs and female musk shrews, may reveal a conserved functional topography in the GnRH1 neuronal system.

\subsection{Anatomically localized effects of positive feedback on GnRH1 in mammals}

Estrous and menstrual cycles involve a period of brief positive feedback in which estrogen indirectly increases GnRH1 neuron activity to enhance gonadotropin stimulation; a period termed the 'LH or GnRH1 surge' (Herbison et al., 2006). Several studies that have employed double label immunocytochemistry for the imme- diate early gene cFos in GnRH1 cells have revealed that discrete sub-populations of GnRH1 are activated during the LH surge (Chan et al., 2011; Lee et al., 1990; Wintermantel et al., 2006). The induction of cFos during the LH surge occurred in approximately $40 \%$ of GnRH1 cells located specifically in the rostral POA (Lee et al., 1990; Wintermantel et al., 2006). Recently, Chan and colleagues (Chan et al., 2011) demonstrated that female GnRH1-green fluorescent protein (GFP) mice exhibit marked plasticity in the somatic spine density in GnRH1 cells across the estrous cycle. Estradiol treated mice exhibited the increase in cFOS expression in the rostral subpopulation of GnRH1 neurons, and these cells were the primary group observed to show increased somatic and dendritic spine density during the LH surge. The increase in spine density was not observed in GnRH1 neurons that did not co-label for cFos or in GnRH1 neurons during the non-surge periods. Furthermore, extensive and complex GnRH1 dendritic trees project into the OVLT and terminate outside the blood-brain barrier (Herde et al., 2011). A large population of these GnRH1 cells exhibits cFos induction during the LH surge, suggesting that this cell group may also contribute to the LH surge independent of the classical bipolar cells that project into the ME (Herde et al., 2011). The presence of dendritic branching outside the blood-brain barrier adds another level of complexity to the function of this unique cell population. For example, in addition to neuromodulatory inputs (e.g., glutamate and kisspeptin), a number of molecules in the periphery can influence GnRH1 activity. Overall, the data support the hypothesis that a discrete subpopulation of GnRH1 cells in the rodent POA is specifically involved in the LH surge.

\section{Co-evolution of neuropeptide plasticity and seasonal reproductive cycles}

As previously discussed, the photoperiod-driven changes in GnRH1 are the one predominant physiological factor regulating the seasonal breeding window in many passeriform species (Ball and Hahn, 1997). In contrast, in the majority of seasonally breeding mammals GnRH1 levels remain constant. There are a few exceptions to this observation such as the case of prairie voles (Microtus ochrogaster) where animals that exhibit photoperiod-induced gonadal regression exhibit an increase in the number of immunoreactive GnRH1 neurons (Kriegsfeld and Nelson, 1999). In addition, based on studies of male Siberian hamsters (Phodopus sungorus) GnRH1 expression seems to increase in a stable population of cells in the POA as the animals transition from experiencing short days to long days (Bernard et al., 1999). Plasticity relevant to changes in the function of the GnRH1 system related variation in the mammalian reproductive cycle was revealed by studies of another neuropeptide. The identification and characterization of a neuropeptide called kisspeptin (KiSS1) provided a significant discovery for understanding the molecular and neural circuits that govern mammalian reproductive cycles (De Roux et al., 2003). Since the discovery of kisspeptin, a number of different isoforms have been isolated and the primary form kiss 1 has been shown to play a critical role in the neuroendocrine regulation of reproduction in a wide range of mammals (Popa et al., 2008; Simonneaux et al., 2009; Smith et al., 2010). In seasonally breeding mammals, in particular the domestic ewe, Syrian hamster (Mesocricetus auratus) and Siberian hamsters, variation in reproductive physiology has been linked to extensive kiss1 plasticity in the hypothalamus, (see Goodman et al. (2010) and Lehman et al. (2010) and Simonneaux et al. (2009) for reviews).

One can generalize about these different patterns of neuropeptide plasticity in birds and mammals. In birds it seems that variation in reproductive physiology is much more apt to correspond directly with variation in the GnRH1 system. For example, several 
papers have discussed the phylogenetic distribution of GnRH1 plasticity in birds and have proposed that variation in GnRH1 plasticity is an adaptive mechanism involved in the timing of reproductive schedules (Hahn and MacDougall-Shackleton, 2008; MacDougall-Shackleton et al., 2009). In mammals it seems to be the case that variation in Kiss1 plasticity relates systematically to variation in reproductive activity. Here we briefly discuss predictability in the neuropeptidergic regulation of seasonal reproduction and then present a phylogenetic comparison of GnRH1 plasticity in birds and Kiss 1 plasticity in mammals. We focus on these two peptides because of the clear roles they play in facilitating reproduction in birds and mammals, respectively. Another peptide, termed Gonadotropin-Inhibitory Hormone $(\mathrm{GnIH}$; the mammalian ortholog, RFamide-related peptide RFRP), was first identified by Tsutsui and colleagues in Japanese quail (Tsutsui et al. (in press) for a review). This dodecapeptide has been shown to be present in the hypothalamus of many avian and mammalian species (Tsutsui et al., in press). It can act in many different ways to inhibit reproduction including direct action on the pituitary to inhibit gonadotropin release (Tsutsui et al., in press). In mammals, changes in photoperiod have been shown to regulate the number of RFRP expressing cells in sheep and hamsters (Mason et al., 2010; Roch et al., 2011), but this does not appear to be the case in birds (Bentley et al., 2003b). There is evidence that other environmental factors, for example, social cues and rainfall, are correlated with variation in GnIH expressing cells in birds (Calisi et al., 2011; Roberts et al., 1989). Indeed RFRP expression is dependent on photoperiodic state and that the interaction of KISS1 and RFRP is important for timing breeding in a number of seasonally breeding mammals (Smith et al., 2008). We do not focus on the GnIH peptide in our discussion because although it clearly plays an important role in the inhibition of reproduction and reproductive behavior (Tsutsui et al., in press) it is still unclear as to whether it plays a primary role in regulating GnRH1 in the context of the photoperiodic modulation of reproduction in birds.

\subsection{Predictability in the control of seasonal reproduction}

Seasonal breeding is a dramatic example of naturally occurring variation in the neuroendocrine control of reproduction. Indeed, seasonally breeding species respond to a diverse range of environmental cues in order to time breeding so that it occurs when conditions are favorable for the survival of their offspring (Ball, 1993; Bronson et al., 1989; Hau, 2001; Immelmann, 1973; Wingfield and Kenagy, 1991; Wingfield, 1988). The constancy/contingency model is an information theoretical approach that has been used to examine periodic cycles in physical and biological phenomena using the concept of predictability (Colwell, 1974). Here, the term constancy is used to describe environmental conditions as predictable because there is little to no change over time. The term contingency is used to describe a variable environment as predictable in the degree to which change is seasonally consistent. The predictability in the annual change to specific environmental cues (e.g., day length) provides a reliable signal that many seasonally reproducing species use to anticipate optimal breeding conditions (Bradshaw and Holzapfel, 2007; Dawson et al., 2001; Goldman, 2001). This approach has been used to illustrate the predictability in seasonal flowering and fruiting in plants (Colwell, 1974), avian gonad cycles (Wingfield et al., 1992) and the neuropeptidergic control of reproductive cycles (Stevenson and Ball, 2011). The constancy/contingency model has been applied to the seasonal variation in GnRH1 expression in a range of bird species (Stevenson and Ball, 2011). The variation in breeding strategies, specifically starlings and white-crowned sparrows, are reflected in the degree of predictability in environmental cues. Specifically, opportunistic or flexibly breeding strategies present in white-crowned sparrows rely more on constancy cues compared to strictly seasonal species (Stevenson and Ball, 2011). In starlings, the change in GnRH1 expression that is driven by photoperiodic cues rely more on a contingency cue, namely day length. A similar pattern was shown for the variation in KiSS1 expression in the hypothalamus of the seasonally breeding Siberian hamster. In this species, variation in KiSS1 expression also changes predictability, primarily attributed to the annual change in day length providing contingency information. There are marked differences in the photoperiodic responses in seasonally breeding birds and mammals. The use of phylogenetic trees provides a means to examine how different photoperiodic responses may have evolved in closely related species and identify how the variation in potential genes (i.e. neuropeptides) may drive the divergence in the species.

\subsection{Photoperiodic regulation of GnRH1 plasticity in birds}

As noted above, not all birds exhibit the same reproductive photoperiodic response. There is a large amount of diversity in the way that birds integrate photoperiodic information leading to the timing of breeding periods (Hahn and MacDougall-Shackleton, 2008). Although a few species of photoperiodic birds may display a fixed threshold for photostimulation (see Lofts and Murton, 1968), most develop some form of photorefractoriness (i.e., the lack of responsiveness to daylengths that previously stimulated reproductive development) after prolonged exposure to long days (Farner and D.S., 1983; Nicholls et al., 1988; Wilson and Donham, 1988). "Absolute photorefractoriness" has operationally been defined by two criteria: (1) the regression of the gonads with no decrease in day length, and (2) once the gonads regress, refractoriness is absolute in the sense that the presence of even longer day lengths cannot re-stimulate gonadal development (Hamner, 1968; MacDougall-Shackleton et al., 2009; Nicholls et al., 1988). Moreover, birds that are in an absolutely photorefractory state seem to be physiologically unresponsive to all previously stimulatory environmental cues (Ball, 1993; Dawson and Sharp, 2007). A second form of photorefractoriness observed in birds is referred to as "relative photorefractoriness" (Nicholls et al., 1988). In species that exhibit relative photorefractoriness, for example the Japanese quail, birds must experience a declining day length in order to initiate gonadal regression, yet birds will resume reproductive competence when presented with longer days (Follett and Maung, 1978; Robinson and Follett, 1982). In the passerine species examined, absolute photorefractoriness is associated with a profound reduction in the amount of GnRH1 mRNA (Stevenson et al., 2009a) and protein (Cho et al., 1998; Dawson et al., 1985; Foster et al., 1987; Goldsmith et al., 1989; Marsh et al., 2002; Park et al., 1988; Pinter and Peczely, 2010) in the POA. Such GnRH1 plasticity is generally observed in birds that exhibit absolute photorefractoriness, and to be absent in birds that exhibit relative photorefractoriness, such as the domestic chicken (Gallus gallus) and Japanese quail (Fig. 3; MacDougall-Shackleton et al., 2009).

Not all passeriform species exhibit absolute photorefractoriness and associated GnRH1 plasticity, and instead show different degrees of responsiveness according to the two criteria for photorefractoriness. For example, photorefractoriness has not been reported in opportunistically breeding birds. Red crossbills do not exhibit gonadal involution in response to constant long days for over 225 days, thus failing to exhibit photorefractoriness according to criterion 1 (Hahn, 1995). In a closely related species, the whitewinged crossbill (Arnaiz-Villena et al., 2001) there is a lack of variation in the GnRH1 immunoreactivity in the POA after prolonged exposure to long days (Pereyra et al., 2005) or when induced to regress the gonads with declining photoperiod (MacDougallShackleton et al., 2001). In addition to the crossbill species, a few other birds in the order passeriformes do not exhibit criterion 1 , 


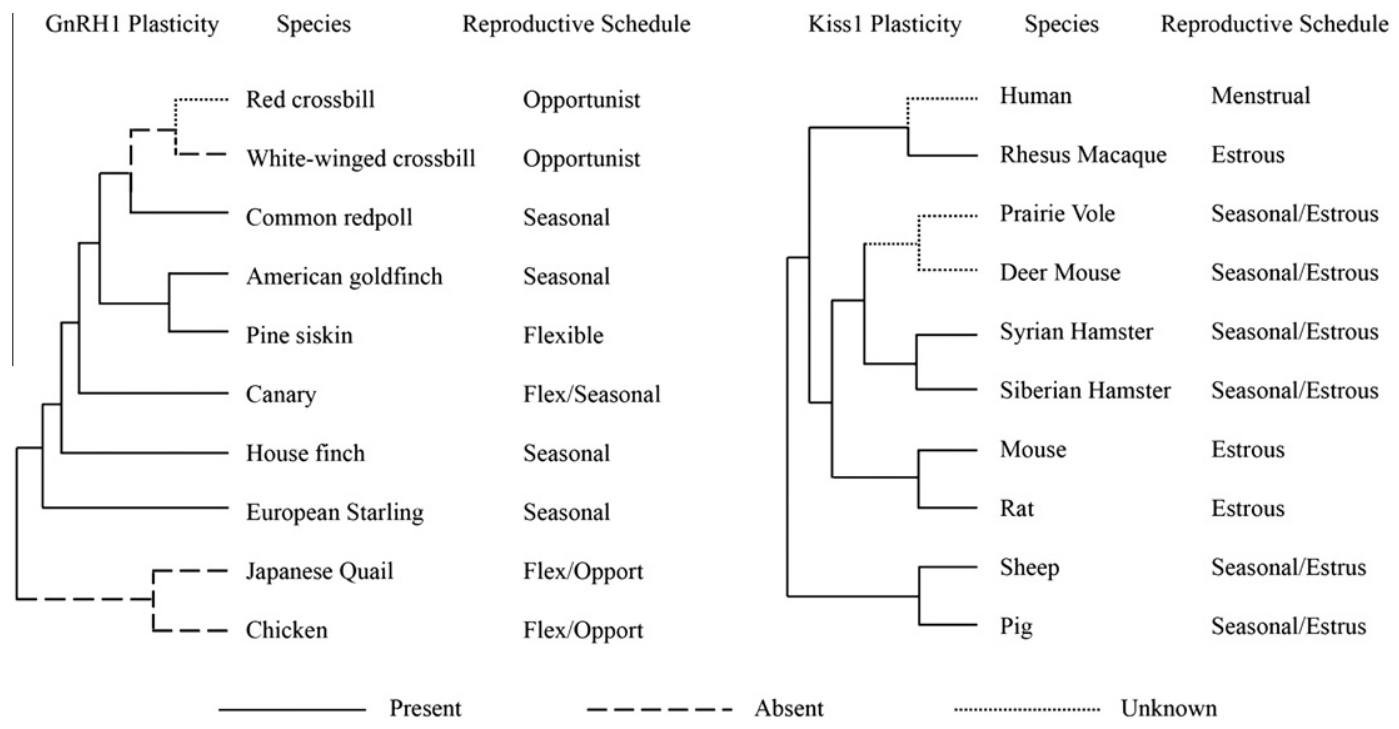

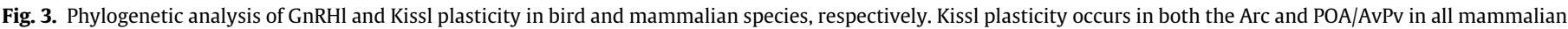

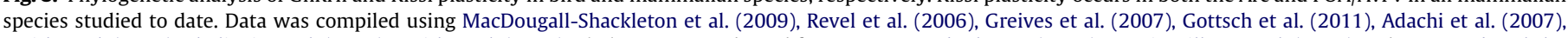

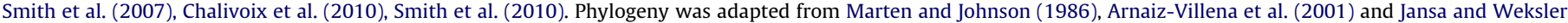
(2004) and Prasad and Allard (2008).

including zebra finches (Hahn et al., 2008) and rufous-winged sparrows (Aimophila carpalis; (Small et al., 2007). The breeding schedules of birds that do not regress their gonads in response to continued long day lengths has evolved in some taxa independently and is hypothesized to be an adaptive specialization for temporal flexibility (Fig. 3; Hahn and MacDougall-Shackleton, 2008; MacDougall-Shackleton et al., 2009). Far fewer species have been tested for criterion 2, but those that have been identified include the tropical antbirds (Hylophylax naevioides; Beebe et al., 2005) and rufous-winged sparrows (Small et al., 2007). Furthermore, the two criteria for absolute photorefractoriness are not necessarily interchangeable. For example, pine siskins (Spinus pinus) spontaneously regress their gonads on long days (pass criterion 1) but will undergo gonadal recrudescence to very long days when photorefractory (fail criterion 2; MacDougall-Shackleton et al., 2006). Pine siskins also down-regulate GnRH1 when photorefractory, but are still able to rapidly respond to very long days even when photorefractory, suggesting an ability to rapidly increase GnRH1 expression (MacDougall-Shackleton et al., 2006; Pereyra et al., 2005), although this interpretation should be viewed with caution, since the siskins tested for criterion 2 had collapsed their gonads on declining photoperiod, not constant long days (also see MacDougall-Shackleton et al., 2006). In the case of moderately flexibly breeding species like the canary, the data for GnRH1 plasticity are quite interesting though they are somewhat hard to interpret because of the possible effects of domestication. Canaries are well known to respond to photoperiod in captivity and exhibit absolute photorefractoriness (e.g., Storey and Nicholls, 1976). In the wild canaries will at times breed in a manner consistent with them being photoperiodic but under favorable conditions they will begin breeding well before daylength increases (Leitner et al., 2003). For this reason they are referred to as being "seasonal opportunistic breeders”(Leitner et al., 2003). There are interesting differences in two canary strains with the American singer strain maintaining high levels of GnRH1 in the presence of prolonged exposure to long days (Bentley et al., 2003a) and the Border strain exhibiting gonadal involution, along with a marked decrease in GnRH1 expression (Hurley et al., 2008). The American singer strain seems to have lost over the course of domestication the native responsiveness to photoperiod that is maintained in the Border strain. In general though it appears based on a comparison of these two strains that gonadal regression is associated with a marked decline in POA GnRH1 (Bentley et al., 2003a; Hurley et al., 2008).

\subsection{Photoperiodic regulation of Kisspeptin plasticity in mammals}

In 2003, the endogenous receptor for the neuropeptide kisspeptin (KiSS1), GPR54, was identified, along with the observation that endogenous and genetically engineered mutation of the Gpr54 gene was associated with hypogonadotropic hypogonadism (De Roux et al., 2003; Seminara et al., 2003). These findings provided a significant step toward elucidating the mechanisms that govern reproductive maturation and hormonal cycling (i.e. estrous and menstrual cycles) in mammals. Several studies have demonstrated that KiSS1 mRNA and protein are mainly expressed in two hypothalamic areas: the arcuate nucleus (Arc) and the anteroventral periventricular nucleus (AVPV; reviewed in Simonneaux et al. (2009)). In primates, KiSS1 mRNA and protein is also expressed in the Arc, but instead of the AVPV, KiSS1 is localized to the POA (Smith et al., 2010). To date, KiSS1 has been shown to exhibit marked plasticity that is either associated with the seasonal breeding state or stage of the estrous/menstrual cycle (Fig. 3). However, the extent of the plasticity and functional significance depends on the anatomical location one considers (Navarro and Tena-Sempere, 2012; Oakley et al., 2009; Popa et al., 2008; Smith et al., 2010).

Two model species that have been used with great success to elucidate the role of KiSS1 in the seasonal control of reproduction are domestic sheep and Siberian and Syrian hamsters. In the ewe, there are many more KiSS1 cells in the medial-caudal Arc and POA during the breeding season, compared to the non-breeding season (i.e. anestrous; Chalivoix et al., 2010; Smith et al., 2007, 2008). This seasonal variation in expression is primarily attributable to the effect of KiSS1 mRNA and protein suppression by estrogen. Studies using ovariectomy and/or hormone replacement have shown that estrogen feedback has a significant negative effect on KiSS1 expression in the Arc (Chalivoix et al., 2010; Smith et al., 2007, 2008). The seasonal change in KiSS1 expression is thought to provide the major input onto GnRH1 terminals and thus regulate the release of GnRH1 (Smith et al., 2008). The data collected to date from hamsters has provided important compara- 
tive information. The initial description of KiSS1 plasticity was identified in Syrian hamsters with greater expression in the Arc in long day (i.e., breeding) males compared to short day (i.e., non-breeding males; Revel et al., 2006). Furthermore, the pattern of KiSS1 expression was reversed in the AVPV (Revel et al., 2006). However, in the closely related species, the Siberian hamster, KiSS1 expression exhibited the opposite pattern in both anatomical regions, with greater expression in the AVPV associated with a breeding state, and higher expression in the Arc associated with a non-breeding state (Greives et al., 2007, 2008; Paul et al., 2009). These data raise interesting questions regarding the role of day length and gonadal steroids in the regulation of KiSS1 plasticity. One hypothesis is that the function of the Arc and AVPV/POA populations are significantly different with the Arc signaling seasonal information required for timing reproduction with the environment, and the AVPV/POA KiSS1 population regulating the GnRH1/LH surge (Clarke et al., 2009; Revel et al., 2007; Simonneaux et al., 2009). It is important to mention that in Syrian hamsters, KiSS1 expression increased in males that developed photorefractoriness to short days (Revel et al., 2006). In many hamster species, prolonged exposure to short day lengths results in insensitivity to the inhibitory effects induced by melatonin resulting in reproductive development (Bittman, 1978). This study suggests that one possible outcome for the development of a photorefractory state in mammals is the reactivation of KiSS1 mRNA/protein expression. It will be an important, yet formidable task to evaluate species variability in the photorefractory response in mammals and evaluate how this relates to KiSS1 plasticity.

In species that time reproduction via estrous or menstrual cycles, there are consistent reports of KiSS1 plasticity (Fig. 4). Rhesus macaques (Macaca mulatta) exhibit KiSS1 plasticity across the estrous cycle with greater levels in the Arc occurring during the GnRH1/LH surge (Smith et al., 2010). This pattern of KiSS1 expres- sion is similar to those reported in the mouse (Gottsch et al., 2011) and rat (Adachi et al., 2007). How variation in KiSS1 plasticity develops across the reproductive schedules is not well defined, but most likely includes a strong gonadal hormone component.

The difference in the reproductive schedules, predominantly highly seasonal or estrous/menstrual cycles may be linked to the integration of environmental and internal signals. For example, the annual change in day length is the predominant cue that drives seasonal reproduction in mammals (Goldman, 2001). The hormone melatonin is a strong physiological read-out of the day length (Reiter, 1991). Thus, the loss of the seasonal control of reproduction may arise from a change in the responsiveness of the KiSS1 cells directly to the melatonin signal or indirectly through another cell population. If this hypothesis is correct, then we should observe a decrease in the sensitivity of KiSS1 neuronal system in species that do not use the annual change in day length to time reproduction (i.e. some laboratory mice and rats). An alternative hypothesis is that dietary intake at a consistently high rate has led to a switch from the hormonal input mediated by day length to a nutritional/metabolic signal. Indeed there is evidence that a lack of sufficient nutrient availability leads to delayed puberty in humans (Foster and Nagatani, 1999). The hormone leptin has been shown to transmit nutritional status to the kisspeptin system and could provide a marker for the emergence of estrous/menstrual cycles (Hameed et al., 2011; True et al., 2011). An alternative to nutritional and/or energy balance, the increase in KiSS1 expression in photorefractory Siberian hamsters provides another route for the loss of photoperiodic gating for the neuroendocrine control of reproduction via KiSS1. Specifically, the melatonin driven decrease in KiSS1 in highly photoperiodic species may have emerged from an increased responsiveness of the KiSS1 neuronal system to the increased duration in the melatonin signal produced under short day lengths. Here, the inhibitory effects of short days on reproduction had adaptive significance for survival in hamsters. Overall,
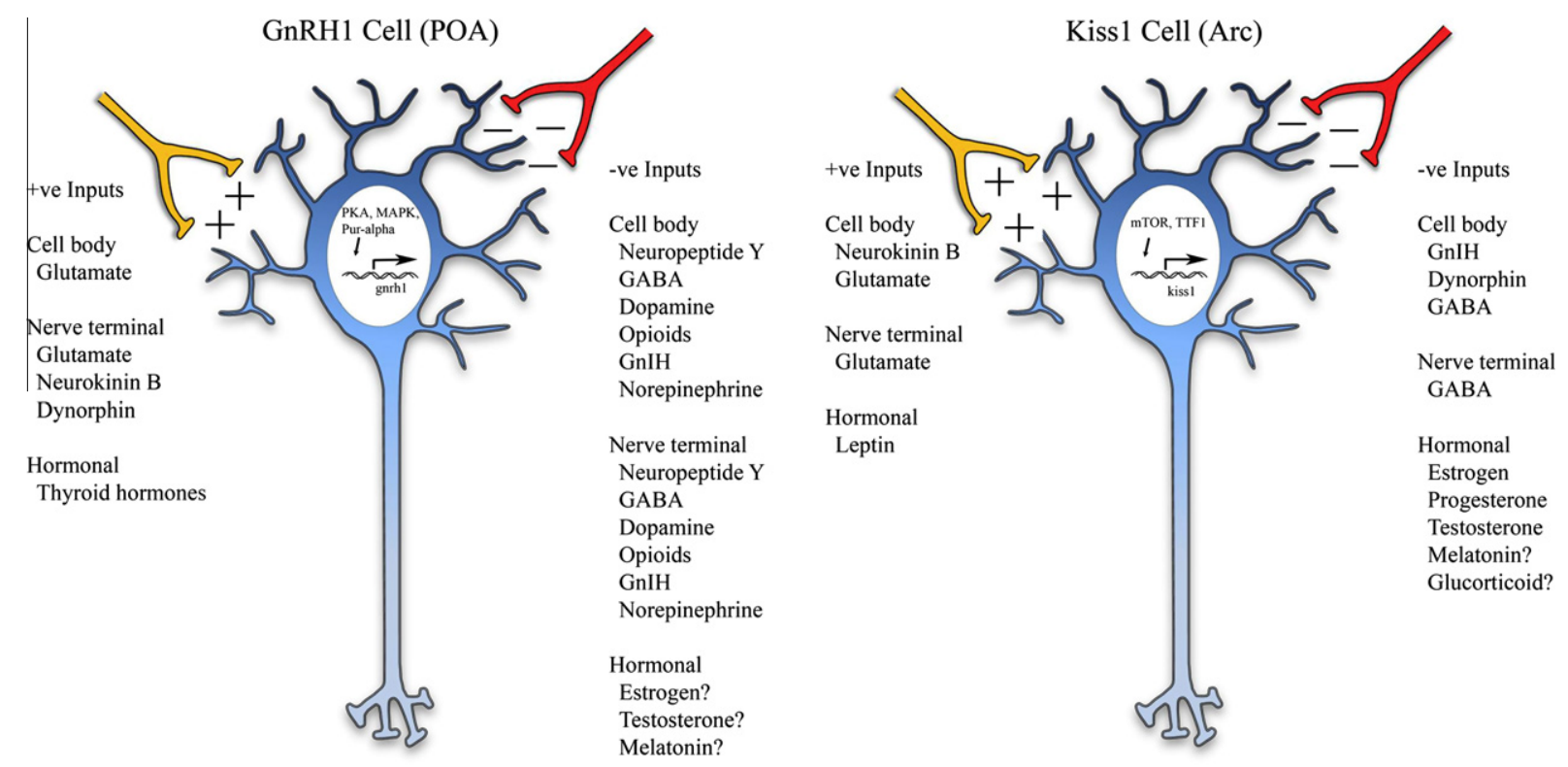

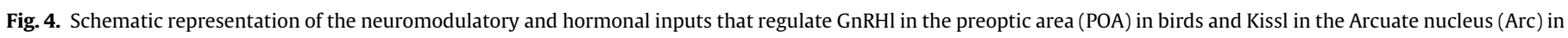

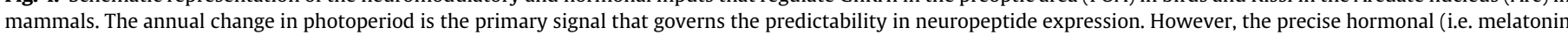

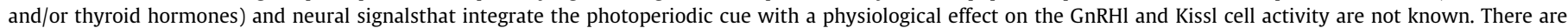

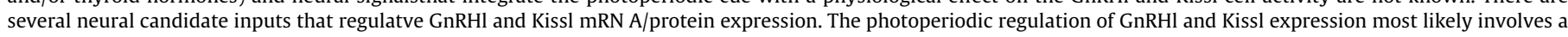

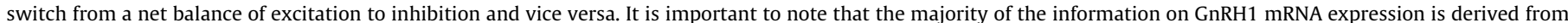

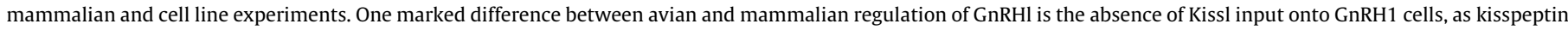

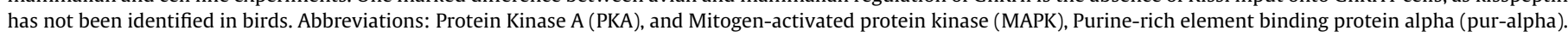

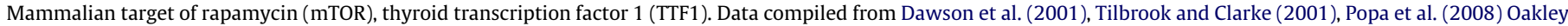
et al. (2009), Xu et al. (2009), Zhao et al. (2010), Mueller et al. (2011), Hameed et al. (2011), True et al. (2011), and Navarro and Tena-Sempere (2012). 
there are three plausible mechanisms that could account for the divergence in the timing of reproductive timing strategies in mammals: (1) a loss in the responsiveness of the KiSS1 neuronal system to melatonin leading to an estrous/menstrual cycle that is not seasonal; (2) a shift from photoperiodic cues to signals that indicate the nutritional state of the organism; and/or (3) an increase in the sensitivity of the KiSS1 neuronal system to melatonin.

\section{Summary and conclusions}

In this paper we have presented data from birds, fish and mammals that suggest the GnRH1 neuronal system exhibits extensive plasticity in response to distinct environmental and internal hormonal signals. Furthermore, we presented findings that reveal a topographic organization of sub-regions of GnRH1 neurons in the POA that are highly sensitive to external cues (i.e. photoperiod, social cues) in birds, and hormonal feedback during the LH surge in rodents. Overall, this review illustrates how - when viewed in a broad comparative context - the GnRH1 neuronal system is highly dynamic and this plasticity evolved for signaling related to the control of reproduction.

\section{Disclosure}

The authors have nothing to disclose.

\section{Acknowledgments}

This work was support by an NSERC to S.M.S.; NSF IOS-0744705 to T.P.H. and NIH/NINDS RO1 35467 to G.F.B.

\section{References}

Adachi, S., Yamada, S., Takatsu, Y., Matsui, H., Kinoshita, M., Takase, K., Sugiura, H., Ohtaki, T., Matsumoto, H., Uenoyama, Y., Tsukamura, H., Inoue, K., Maeda, K., 2007. Involvement of anteroventral periventricular metastin/kisspeptin neurons in estrogen positive feedback action on luteinizing hormone release in female rats. J. Reprod. Dev. 53, 367-378.

Altman, J., 1969. Autoradiographic and histological studies of postnatal neurogenesis. IV. Cell proliferation and migration in the anterior forebrain, with special reference to persisting neurogenesis in the olfactory bulb. J. Comp. Neurol. 137, 433-457.

Altman, J., Das, G.D., 1965. Post-natal origin of microneurones in the rat brain. Nature 28, 953-956.

Arnaiz-Villena, A., Guillen, J., Ruiz-del-Valle, V., Lowy, E., Zamora, J., Varela, P., Stefani, D., Allende, L.M., 2001. Phylogeography of crossbills, bullfinches, grosbeaks and rosefinches. Cell. Mol. Life Sci. 58, 1159-1166.

Ball, G.F., 1993. The neural integration of environmental information by seasonally breeding birds. Am. Zool. 33, 185-199.

Ball, G.F., Balthazart, J., 2002. Neuroendocrine mechanisms regulating reproductive cycles and reproductive behavior in birds. In: Pfaff, D., Arnold, A., Etgen, A. Fahrbach, S., Rubin, R. (Eds.), Hormones, Brain and Behavior. Academic Press, Elsevier Science, USA.

Ball, G.F., Balthazart, J., 2004. Hormonal regulation of brain circuits mediating male sexual behavior in birds. Physiol. Behav. 83, 329-346.

Ball, G.F., Hahn, T.P., 1997. GnRH1 neuronal systems in birds and their relation to the control of seasonal reproduction. In: Parhar, I.S., Sakuma, Y. (Eds.), GnRH1 Neurons: Gene to Behavior. Brain Shuppan, Tokyo, Japan.

Ball, G.F., Ketterson, E.D., 2008. Sex differences in the response to environmental cues regulating seasonal reproduction in birds. Philos. Trans. Roy. Soc. Lond. B: Biol. Sci. 363, 231-246.

Ball, G.F., Riters, L.V., Balthazart, J., 2002. Neuroendocrinology of song behavior and avian brain plasticity: multiple sites of action of sex steroid hormones. Front. Neuroendocrinol. 23, 137-178.

Balthazart, J., Ball, G.F., 2007. Topography in the preoptic regions: differential regulation of appetitive and consummatory male sexual behaviors. Front. Neuroendocrinol. 28, 161-178.

Balthazart, J., Absil, P., Gerard, M., Appeltants, D., Ball, G.F., 1998. Appetitive and consummatory male sexual behavior in Japanese quail are differentially regulated by subregions of the preoptic medial nucleus. J. Neurosci. 18, 65126527.

Barry, J., 1979. Immunohistochemistry of luteinizing hormone-releasing hormone producing neurons of the vertebrates. Int. Rev. Cytol. 60, 179-221.

Bear, M.F., Malenka, R.C., 1994. Synaptic plasticity: LTP and LTD. Curr. Opin. Neurobiol. 4, 389-399.
Beebe, K., Bentley, G.E., Hau, M., 2005. A seasonally breeding tropical bird lacks absolute photorefractoriness in the wild, despite high photoperiodic sensitivity. Funct. Ecol. 19, 505-512.

Bentley, G.E., Audage, N.C., Hanspal, E.K., Ball, G.F., Hahn, T.P., 2003a. Photoperiodic response of the hypothalamo-pituitary-gonad axis in male and female canaries, Serinus canaria. J. Exp. Zool. A 296, 143-151.

Bentley, G.E., Perfito, N., Ukena, K., Tsutsui, K., Wingfield, J.C., 2003b. Gonadotropininhibitory peptide in song sparrows (Melospiza melodia) in different reproductive conditions, and in house sparrows (Passer domesticus) relative to chicken-gonadotropin-releasing hormone. J. Neuroendocrinol. 15, 794802 .

Bernard, D.J., Abuav-Nussbaum, R., Horton, T.H., Turek, F.W., 1999. Photoperiodic effects on gonadotropin releasing hormone content and the $\mathrm{GnRH}$ immunoreactive neuronal system of male Siberian hamsters. Biol. Reprod. 60, $272-276$.

Bhardwaj, R.D., Curtis, M.A., Spalding, K.L., Buchholz, B.A., Fink, D., Bjork-Eriksson, T. Nordborg, C., Gage, F.H., Druid, H., Eriksson, P.S., Frisen, J., 2006. Proc. Natl. Acad. Sci. $15,12564-12568$.

Bittman, E.L., 1978. Hamster refractoriness: the role of insensitivity of pineal target issues. Science 202, 648-649.

Bradshaw, W.E., Holzapfel, C.M., 2007. Evolution of animal photoperiodism. Annu. Rev. Ecol. Evol. Syst. 38, 1-25.

Brann, D.W., Mahesh, V.B., 1997. Excitatory amino acids: evidence for a role in the control of reproduction and anterior pituitary hormone secretion. Endocr. Rev. $18,678-700$.

Brenowitz, E.A., 2004. Plasticity of the adult avian song control system. Ann. N.Y. Acad. Sci. 1016, 560-585.

Bronson, F.H., 1989. Seasonal strategies. In: Mammalian Reproductive Biology. The University of Chicago Press, Chicago, IL.

Burgus, R., Butcher, M., Amoss, M., Ling, N., Monahan, M., Rivier, J., Fellows, R. Blackwell, R., Vale, W., Guillemin, R., 1972. Primary structure of the ovine hypothalamic luteinizing hormone-releasing factor (LRF) (LH-hypothalamusLRF-gas chromatography-mass spectrometry-decapeptide-Edman degradation). Proc. Natl. Acad. Sci. USA 69, 278-282.

Burmeister, S.S., Wilczynski, W., 2005. Social signals regulate GnRH neurons in the green treefrog. Brain Behav. Evol. 65, 26-32.

Burmeister, S.S., Kailasanath, V., Fernald, R.D., 2007. Social dominance regulates androgen and estrogen receptor gene expression. Horm. Behav. 51, 164170 .

Calisi, R.M., Diaz-Munoz, S.L., Wingfield, J.C., Bentley, B.E., 2011. Social and breeding status are associated with the expression of GnIH. Genes Brain Behav. 10, 557564

Chalivoix, S., Bagnolini, A., Caraty, A., Cognie, J., Malpaux, B., Dufourny, L., 2010. Effects of photoperiod on kisspeptin neuronal populations of the ewe diencephalon in connection with reproductive function. J. Neuroendocrinol. 22, 110-118.

Chan, H., Rescott, M., Ong, Z., Herde, M.K., Herbison, A.E., Campbell, R.E., 2011 Dendritic spine plasticity in gonadotropin releasing hormone neurons activated at the time of the preovulatory surge. Endocrinology 152, 4906-4914.

Cheng, M.F., 1977. Role of gonadotropin-releasing hormones in reproductive behavior of female ring doves. J. Endocrinol. 74, 37-45.

Cheng, M.F., 1992. For whom does the female dove coo? A case for the role for the vocal self-stimulation. Anim. Behav. 43, 1035-1044.

Cheng, M.F., 1993. Vocal, auditory, and endocrine systems: three-way connectivity and implications. Poult. Sci. Rev. 4, 37-47.

Cheng, M.F., Peng, J.P., 1997. Reciprocal talk between the auditory thalamus and the hypothalamus: an antidromic study. NeuroReport 8, 653-658.

Cheng, M.F., Desiderio, C., Havens, M., Johnson, A., 1988. Behavioral stimulation of ovarian growth. Horm. Behav. 22, 388-402.

Cheng, M.F., Peng, J.P., Johnson, P., 1998. Hypothalamic neurons preferentially respond to female nest coo stimulation: demonstration of direct acoustic stimulation of luteinizing hormone release. J. Neurosci. 18, 5477-5489.

Cheng, M.F., Alexander, K., Zhou, S., Bonder, E., Chuang, L.S., 2011. Newborn GnRH neurons in the adult forebrain of the ring dove. Horm. Behav. 60, 94104.

Cho, R.N., Hahn, T.P., MacDougall-Shackleton, S.A., Ball, G.F., 1998. Seasonal variation in brain GnRH in free-living breeding and photorefractory house finches. Gen Comp. Endocrionl. 109, 44-50.

Christal, K.A., 2001. Seasonal changes in hypothalamic GnRH in the white-winged crossbill, Loxia leucoptera. Princeton University Senior Thesis No. 12965.

Clarke, I.J., Smith, T.J., Caraty, A., Goodman, R.L., Lehman, M.N., 2009. Kisspeptin and seasonality in sheep. Peptides 30, 154-163.

Colwell, R.K., 1974. Predictability, constancy and contingency of periodic phenomena. Ecology 55, 1148-1153.

Dawson, A., 2003. Photoperiodic control of the annual cycle in birds and comparison with mammals. Ardea 90, 355-367.

Dawson, A., 2005. Seasonal differences in the secretion of luteinizing hormone and prolactin in response to $\mathrm{N}$-methyl-DL-aspartate in starlings. J. Neuroendocrinol. $17,105-110$.

Dawson, A., Goldsmith, A.R., 1997. Changes in gonadotropin-releasing hormone in the preoptic area and median eminence of starlings during the recovery of photosensitivity and during photostimulation. J. Reprod. Fertil. 111, 1-6.

Dawson, A., Sharp, P.J., 2007. Photorefractoriness in birds - photoperiodic and nonphotoperiodic control. Gen. Comp. Endocrinol. 153, 378-384.

Dawson, A., Follett, B.K., Goldsmith, A.R., Nicholls, T.J., 1985. Hypothalamic gonadotrophin-releasing hormone and pituitary and plasma $\mathrm{FSH}$ and 
prolactin during photostimulation and photorefractoriness in intact and thyroidectomized starlings (Sturnus vulgaris). J. Endocrinol. 105, 71-77.

Dawson, A., King, V.M., Bentley, G.E., Ball, G.F., 2001. Photoperiodic control of seasonality in birds. J. Biol. Rhythms 16, 365-380.

Dawson, A., Talbot, R.T., Dunn, I.C., Sharp, P.J., 2002. Changes in basal hypothalamic chicken gonadotropin-releasing hormone-I and vasoactive intestinal polypeptide associated with a photo-induced cycle in gonadal maturation and prolactin secretion in intact and thyroidectomized starlings (Sturnus vulgaris). J. Neuroendocrinol. 14, 533-539.

De Roux, N., Genin, E., Carel, J.C., Matsuda, F., Chaussain, J.L., Milgrom, E., 2003. Hypogonadotropic hypogonadism due to loss of function of the KiSS1-derived peptide receptor GPR54. Proc. Natl. Acad. Sci. USA 100, 10972-10976.

Dellovade, T.L., Rissman, E.F., 1994. Gonadotropin-releasing hormone immunoreactive cell numbers change in response to social interactions. Endocrinology 134, 2189-2197.

Deviche, P., Saldanha, C.J., Silver, R., 2000. Changes in brain gonadotropin-releasing hormone- and vasoactive intestinal polypeptide-like immunoreactivity accompanying reestablishement of photosensitivity in male dark-eyed juncos. Gen. Comp. Endocrinol. 117, 8-19.

Deviche, P., Small, T., Sharp, P.J., Tsutsui, K., 2006. Control of luteinzing hormone and testosterone secretion in a flexibly breeding male passerine, the Rufous-winged sparrow, Aimophila carpalis. Gen. Comp. Endocrinol. 149, 226-235.

Deviche, P., Sabo, J., Sharp, P.J., 2008. Glutamatergic stimulation of luteinizing hormone secretion in relatively refractory songbirds. J. Neuroendocrinol. 20, 1191-1202.

Ebling, F.J., Cronin, A.S., 1998. Manipulations of glutamatergic neurotransmission alter the rate of photoperiodically regulated sexual maturation in the male Siberian hamster. Biol. Reprod. 58, 1-7.

Ebling, F.J., Alexander, I.H., Urbanski, H.F., Hastings, M.H., 1995. Effects of N-methylD-aspartate on seasonal cycles of reproduction, body weight and pelage color in the male Siberian hamster. J. Neuroendocrinol. 7, 555-566.

Eriksson, P.S., Perfilieva, E., Bjork-Eriksson, T., Alborn, A.M., Nordborg, C., Peterson, D.A., Gage, F.H., 1998. Neurogenesis in the adult human hippocampus. Nat. Med. 4, 1313-1317.

Farner, D.S., Donham, R.S., Matt, K.S., Mattocks, P.W., Jr., Moore, M.C., Wingfield, J.C., 1983. The nature of photorefractoriness. In: Mikami, S.I., Homma, K., Wada, M. (Eds.), Avian Endocrinology: Environmental and Ecological Perspectives. Japan Scientific Society Press; Springer, Tokyo, Japan; Berlin, Germany, pp. 149-156.

Fernald, R.D., Hirata, N.R., 1977. Field study of Haplochromis burtoni quantitative behavioral observations. Anim. Behav. 25, 964-975.

Fernald, R.D., White, R.B., 1999. Gonadotropin-releasing hormone genes: phylogeny, structure and functions. Front. Neuroendocrinol. 20, 224-240.

Follett, B.K., Maung, S.L., 1978. Rate of testicular maturation, in relation to gonadotropin and testosterone levels in quail exposed to various artificial photoperiods and to natural daylengths. J. Endocrinol. 78, 267-280.

Foster, D.L., Nagatani, S., 1999. Physiological perspectives on leptin as a regulator of reproduction: role in timing puberty. Biol. Reprod. 60, 205-215.

Foster, R.G., Plowman, G., Goldsmith, A.R., Follett, B.K., 1987. Immunohistochemical demonstration of marked changes in the LHRH system of photosensitive and photorefractory European starlings. J. Endocrinol. 115, 211-220.

Francis, R.C., Jacobson, B., Wingfield, J.C., Fernald, R.D., 1992. Hypertrophy of gonadotropin releasing hormone containing neurons after castration in the teleost. J. Neurobiol. 23, 1084-1093.

Garcia-Segura, L.M., Suarez, I., Segovia, S., Tranque, P.A., Cales, J.M., Aguilera, P., Olmos, G., Guillamon, A., 1988. The distribution of glial fibrillary acidic protein in the adult rat brain is influenced by the neonatal levels of sex steroids. Brain Res. 26, 357-363.

Goldman, B.D., 2001. Mammalian photoperiodic system: formal properties and neuroendocrine mechanisms of photoperiodic time measurement. J. Biol. Rhythms 16, 263-283.

Goldsmith, A.R., Ivings, W.E., Pearce-Kelly, A.S, Parry, D.M., Plowman, G., Nicholls, T.J., Follett, B.K., 1989. Photoperiodic control of the development of the LHRH neurosecretory system of European starlings during puberty and the onset of photorefractoriness. J. Endocrinol. 122, 255-268.

Goodman, R.L., Jansen, H.T., Billings, H.J., Coolen, L.M., Lehman, M.N., 2010. Neural systems mediating seasonal breeding in the Ewe. J. Neuroendocrinol. 22, 674681.

Gorbman, A., Sower, S.A., 2003. Evolution of the role of GnRH in animal biology. Gen. Comp. Endocrinol. 134, 207-213.

Gore, A.C., Roberts, J.L., Gibson, M.J., 1999. Mechanisms for the regulation of gonadotropin-releasing hormone gene expression in the developing mouse. Endocrinology 140, 2280-2287.

Gore, A.C., 2002. GnRH1: The Master Molecule of Reproduction. Kluwer Academic Publishers, Norwell, Mass., USA.

Gottsch, M.L., Popa, S.M., Lawhorn, J.K., Qiu, J., Tonsfeldt, K.J., Bosch, M.A., Kelly, M.J., Ronnekleiv, O.K., Sanz, E., McKnight, G.S., Clifton, D.K., Palmiter, R.D., Steiner, R.A., 2011. Molecular properties of Kiss1 neurons in the arcuate nucleus of the mouse. Endocrinology 152, 4298-4309.

Gould, E., 2007. How widespread is adult neurogenesis in mammals? Nat. Rev. Neurosci. 8, 481-488.

Greives, T.J., Mason, A.O., Scotti, M.A., Levine, J., Ketterson, E.D., 2007. Environmental control of kisspeptin: implications for seasonal reproduction. Endocrinology $148,1158-1166$.

Greives, T.J., Humber, S.A., Goldstein, A.N., Scotti, M.A., Demas, G.E., Kriegsfeld, L.J., 2008. Photoperiod and testosterone interact to drive seasonal changes in kisspeptin expression in Siberian hamsters. J. Neuroendocrinol. 20, 1339-1347.
Hahn, T.P., 1995. Integration of photoperiodic and food cues to time changes in reproductive physiology by an opportunistic breeder, the red crossbill. J. Exp. Zool. 272, 213-226.

Hahn, T.P., Ball, G.F., 1995. Changes in brain GnRH associated with photorefractoriness in house sparrows. Gen. Comp. Endocrinol. 99, 349-363.

Hahn, T.P., MacDougall-Shackleton, S.A., 2008. Adaptive specialization, conditional plasticity and phylogenetic history in the reproductive cue response system of birds. Phil. Trans. Roy. Soc. 363, 267-286.

Hahn, T.P., Cornelius, J.M., Sewall, K.B., Kelsey, T.R., Hau, M., Perfito, N., 2008 Environmental regulation of annual schedules in opportunistically-breeding songbirds: adaptive specializations or variation on a theme of white-crowned sparrow? Gen. Comp. Endocrinol. 157, 217-226.

Hameed, S., Jayasena, C.N., Dhillo, W.S., 2011. Kisspeptin and fertility. J. Endocrinol 208, 97-105

Hamner, WM., 1968. The photorefractory period of the house finch. Ecology 49, 211-227.

Hau, M., 2001. Timing of breeding in variable environments: tropical birds as model systems. Horm. Behav. 40, 281-290.

Herbison, A.E., 1998. Multimodal influence of estrogen upon gonadotropinreleasing hormone neurons. Endocrine Rev. 19, 302-330.

Herbison, A.E., 2006. Physiology of the gonadotropin-releasing hormone neuronal network. In: Neill, J.D. (Ed.), Knobil and Neill's Physiology of Reproduction, third ed. Raven Press, New York, NY.

Herde, M.K., Geist, K., Campbell, R.E., Herbison, A.E., 2011. Gonadotropin-releasing hormone neurons extend complex highly branched dendritic trees outside the blood-brain barrier. Endocrinology 152, 3832-3841.

Hinde, R.A., 1965. Interaction of internal and external factors in integration of canary reproduction. In: Beach, F. (Ed.), Sex and Behavior. John Wiley and Sons, New York, pp. 381-415.

Hoffmann, H.A., 2006. Gonadotropin releasing hormone signaling in behavioral plasticity. Curr. Opin. Neurobiol. 16, 343-350.

Hurley, L.L., Wallace, A.M., Sartor, J.J., Ball, G.F., 2008. Photoperiodic induced change sin reproductive state of border canaries are associated with marked variation in hypothalamic gonadotropin-releasing hormone immunoreactivity and the volume of song control regions. Gen. Comp. Endocrinol. 158, 10-19.

Immelmann, K., 1973. Role of the environment in reproduction as a source of predictive information. In: Farner, D.S. (Ed.), Breeding Biology of Birds. National Academy of Sciences, USA, pp. 121-147.

Jansa, S.A., Weksler, M., 2004. Phylogeny of muroid rodents: relationship within and among major lineages as determined by IRBP gene sequences. Mol. Phylogenet. Evol. 31, 256-276.

Jasoni, C.L., Romano, N., Constantin, S., Lee, K., Herbison, A.E., 2010. Calcium dynamics in gonadotropin-releasing hormone neurons. Front. Neuroendocrinol. 31, 259-269.

Kelly, M.J., Garrett, J., Bosch, M.A., Roselli, C.E., Douglass, J., Adelman, J.P., Ronnekleiv, O.K., 1989. Effects of ovariectomy on GnRH mRNA, proGnRH and $\mathrm{GnRH}$ levels in the preoptic hypothalamus of the female rat. Neuroendocrinology 49, 88-97.

King, J.A., Millar, R.P., 1992. Evolution of gonadotropin-releasing hormones. Trends Endocrinol. Metab. 3, 339-346.

Kobayashi, R.M., Lu, K.H., Moore, R.Y., Yen, S.S.C., 1978. Regional distribution of hypothalamic LHRH in proestrous rats: effects of ovariectomy and of estrogen replacement. Endocrinology 102, 98-105.

Kriegsfeld, L.J., Nelson, R.J., 1999. Photoperiod affects the gonadotropin releasing hormone neuronal system of male prairie voles. Neuroendocrinology 69, 238 244.

Lee, W.S., Smith, M.S., Hoffman, G.E., 1990. Luteinizing hormone-releasing hormone neurons express Fos protein during the proestrous surge of luteinizing hormone. Proc. Nat. Acad. Sci. USA 87, 5163-5167.

Lehman, M.N., Silverman, A.J., 1988. Ultrastructure of luteinizing hormone releasing hormone LHRH neurons and their projections in the golden hamster. Brain Res. Bull. 20, 211-221.

Lehman, M.N., Karsch, F.J., Robinson, J.E., Silverman, A.J., 1988. Ultrastructure and synaptic organization of LHRH neurons in the anestrous ewe. J. Comp. Neurol. 273, 447-458.

Lehman, M.N., Ladha, Z., Coolen, L.M., Hileman, S.M., Connors, J.M., Goodman, R.L., 2010. Neuronal plasticity and seasonal reproduction in sheep. Eur. J. Neurosci. 32, 2152-2164.

Lehrman, D., 1965. Interaction between internal and external environments in the regulation of the reproductive cycle of the ring dove. In: Beach, F.A. (Ed.), Sex and Behavior. Wiley, New York, pp. 355-379.

Leitner, S., Van't Hof, T.J., Gahr, M., 2003. Flexible reproduction in wild canaries is independent of photoperiod. Gen. Comp. Endocrinol. 130, 102-108.

Lofts, B., Murton, R.K., 1968. Photoperiodic and physiological adaptations regulating avian breeding cycles and their ecological significance. J. Zool. 155, 327394.

MacDougall-Shackleton, S.A., Deviche, P.J., Crain, R.D., Ball, G.F., Hahn, T.P., 2001 Seasonal changes in brain GnRH immunoreactivity and song control nucle volumes in an opportunistically breeding songbird. Brain Behav. Evol. 58, 3848.

MacDougall-Shackleton, S.A., Katti, M., Hahn, T.P., 2006. Tests of absolute photorefractoriness in four species of cardueline finch that differ in reproductive schedules. J. Exp. Biol. 209, 3786-3794.

MacDougall-Shackleton, S.A., Stevenson, T.J., Watts, H.E., Pereyra, M.E., Hahn, T.P., 2009. The evolution of photoperiod response systems and seasonal GnRH1 plasticity in birds. Integr. Comp. Biol. 49, 580-589. 
Malenka, R.C., Bear, M.F., 2004. LTP and LTD: an embarrassment of riches. Neuron $30,5-21$

Malik, K.F., Silverman, A.J., Morrell, J.I., 1991. Gonadotropin releasing hormone mRNA in the rat. Distribution and neuronal content over the estrous cycle and after castration in males. Anat. Rec. 231, 457-466.

Maney, D.L., Richardson, R.D., Wingfield, J.C., 1997. Central administration of gonadotropin releasing hormone II enhances copulatory behavior in a female sparrow. Horm. Behav. 32, 11-18.

Maney, D.L., Goode, C.T., Lake, J.I., Lange, H.S., O’Brien, S., 2007. Rapid neuroendocrine responses to auditory courtship signals. Endocrinology 148, 5614-5623.

Mantei, K.E., Ramakrishnan, S., Sharp, P.J., Buntin, J.D., 2008. Courtship interactions stimulate rapid changes in GnRH synthesis in male ring doves. Horm. Behav. 54, 669-675.

Marsh, R.H., MacDougall-Shackleton, S.A., Hahn, T.P., 2002. Photorefractoriness and seasonal change in the brain in response to changes in day length in American goldfinches. Can. J. Zool. 80, 2100-2107.

Marten, J.A., Johnson, N.K., 1986. Genetic relationships of North American cardueline finches. Condor 88, 409-420.

Maruska, K.P., Levavi-Sivan, B., Biran, J., Fernald, R.D., 2010. Plasticity of the reproductive axis caused by social status change in an african cichlid fish: I. Pituitary gonadotropins. Endocrinology 152, 281-290.

Mason, A.O., Duffy, S., Zhao, S., Ubuka, T., Bentley, G.E., Tsutsui, K., Silver, R. Kriegsfeld, L.J., 2010. Photoperiod and reproductive condition are associated with changes in RF-amide related peptide expression in Syrian hamsters. J. Biol. Rhythms 25, 176-185.

Meddle, S.L., Maney, D.L., Wingfield, J.C., 1999. Effects of N-methyl-D-aspartate on luteinizing hormone release and Fos-like immunoreactivity in the male whitecrowned sparrow. Endocrinology 140, 5922-5928.

Meddle, S.L., Wingfield, J.C., Millar, R.P., Deviche, P.J., 2006a. Hypothalamic GnRH1 and its precusor during photorefractoriness onset in free living male dark-eyed juncos of different year classes. Gen. Comp. Endocrinol. 145, 148-156.

Meddle, S.L., Bush, S., Sharp, P.J., Millar, R.P., Wingfield, J.C., 2006b. Hypothalamic pro-GnRH-GAP, GnRH1 and GnRH2 during the onset of photorefractoriness in the white-crowned sparrow. J. Neuroendocrinol. 18, 217-226.

Meredith, J.M., Turek, F.W., Levine, J.E., 1991. Pulsatile luteinizing hormone responses to intermittent $\mathrm{N}$-methyl-D, $\mathrm{L}$ aspartate administration in hamsters exposed to long and short day photoperiods. Endocrinology 129, 17141720.

Moenter, S.M., DeFazio, R.A., Pitts, G.R., Nunemaker, C.S., 2003. Mechanisms underlying episodic gonadotropin-releasing hormone secretion. Front. Neuroendocrinol. 24, 79-93.

Moore, I.T., Bentley, G.E., Wotus, C., Wingfield, J.C., 2006. Photoperiod-independent changes in immunoreactive brain gonadotropin-releasing hormone $(\mathrm{GnRH})$ in a free-living tropical bird. Brain Behav. Evol. 68, 37-44.

Moss, R., McCann, S.M., 1973. Induction of mating behavior in rats by luteinizing hormone-releasing factor. Science 181, 177-179.

Muske, L.E., 1993. Evolution of gonadotropin-releasing hormone neuronal system. Brain Behav. Evol. 42, 215-230.

Navarro, V.M., Tena-Sempere, M., 2012. Neuroendocrine control by kisspeptins: role in metabolic regulation of fertility. Nat. Rev. Endocrinol. 8, 40-53.

Nicholls, T.J., Goldsmith, A.R., Dawson, A., 1988. Photorefractoriness in birds and comparison with mammals. Physiol. Rev. 68, 133-176.

Nottebohm, F., 1985. Neuronal replacement in adulthood. Ann. N.Y. Acad. Sci. 457 143-161.

Nottebohm, F., 1989. From birdsong to neurogenesis. Sci. Am. 260, 74-79.

Oakley, A.E., Clifton, D.K., Steiner, R.A., 2009. Kisspeptin signaling in the brain. Endocr. Rev. 30, 713-743.

Okubo, K., Nagahama, Y., 2008. Structural and functional evolution of gonadotropinreleasing hormone in vertebrates. Acta Physiol. 193, 3-15.

Okuzawa, K., Amano, M., Kobayashi, M., Aida, K., Hanyu, I., Hasegawa, Y., Miyamoto, K., 1990. Differences in salmon GnRH and chicken GnRH-2 contents in discrete brain-areas of male and female rainbow-trout according to age and stage of maturity. Gen. Comp. Endocrinol. 80, 116-126.

Panzica, G.C., Viglietti-Panzica, C., Balthazart, J., 1996. The sexually dimorphic medial preoptic nucleus of quail: a key brain area mediating steroid action on male sexual behavior. Front. Neuroendocinol. 17, 51-125.

Park, Y., Park, S.D., Cho, W.K., Kim, K., 1988. Testosterone stimulates LHRH like mRNA level in the rat hypothalamus. Brain Res. 451, 255-260.

Parry, D.M., Goldsmith, A.R., Millar, R.P., Glennie, L.M., 1997. Immunocytochemical localization of $\mathrm{GnRH}$ precursor in the hypothalamus of European starlings during sexual maturation and photorefractoriness. J. Neuroendocrionl. 9, 235243.

Paul, M.J., Pyter, L.M., Freeman, D.A., Galang, J., Prendergsat, B.J., 2009. Photic and non-photic seasonal cues differentially engage hypothalamic kisspeptin an rfamide-related peptide mRNA expression Siberian hamsters. J. Neuroendocrinol. 21, 1007-1014.

Pereyra, M.E., Sharbaugh, S.M., Hahn, T.P., 2005. Interspecific variation in photoinduced GnRH plasticity among nomadic cardueline finches. Brain Behav. Evol $66,35-49$.

Pfaff, D.W., 1973. Luteinizing hormone-releasing factor potentiates lordosis behavior in hypophysectomized ovariectomized female rats. Science 182 1148-1149.

Pfaff, D.W., Kow, L.M., Loose, M.D., Flanagan-Cato, L.M., 2008. Reverse engineering the lordosis behavior circuit. Horm. Behav. 54, 347-354.
Pinter, O., Peczely, P., 2010. Seasonal changes in hypothalamic gonadotropin releasing hormone immunoreactivity in relation to testicular volume in adult male free-living European starlings. Acta Biol. Hung. 61, 237-249.

Popa, S.M., Clifton, D.K., Steiner, R.A., 2008. The role of kisspeptins and GPR54 in the neuroendocrine regulation of reproduction. Annu. Rev. Physiol. 70, 213-238.

Prasad, A.B., Allard, M.W., 2008. NISC comparative sequencing program, Green ED. Confirming the phylogeny of mammals by use of large comparative sequence data sets. Mol. Biol. Evol. 25, 1795-1808.

Prevot, V., Hanchate, N.K., Bellefontaine, N., Sharif, A., Parkash, H., Estrella, C., Allet, C., de Seranno, S., Campagne, C., d'Anglemont de Tassigny, X., Baroncini, M., 2010. Function-related structural plasticity of the GnRH1 system. A role for neuronal-glial-endothelial interactions. Front. Neuroendocrinol. 31, 241-258.

Reinert, B.D., Wilson, F.E., 1996. The thyroid and the hypothalamuspituitary-ovarian axis in American tree sparrows. Gen. Comp. Endocrinol. 103, 60-70.

Reiter, R.J., 1991. Pineal-gland - interface between the photoperiodic environment and the endocrine system. Trends Endocrinol. Metab. 2, 13-19.

Revel, F.G., Saboureau, M., Masson-Pevet, M., Pevet, P., Mikkelsen, J.D., Simmoneaux, V., 2006. Kisspeptin mediates the photoperiodic control of reproduction in hamsters. Curr. Biol. 16, 1730-1735.

Revel, F.G., Ansel, L., Klosen, P., Saboureau, M., Pevet, P., Mikkelsen, J.D., Simmoneaux, V., 2007. Kisspeptin: a key link to seasonal breeding. Rev. Endocr. Metab. Disord. 8, 57-65.

Rissman, E.F., 1996. Behavioral regulation of Gonadotropin releasing hormone. Biol. Reprod. 54, 413-419.

Riters, L.V., Ball, G.F., 1999. Lesions to the medial preoptic area affect singing in the male European starling (Sturnus vulgaris). Horm. Behav. 36, 276-286.

Riters, L.V., Teague, D.P., Schroeder, M.B., Cummings, S.E., 2004. Vocal production in different social contexts relates to variation in immediate early gene immunoreactivity within and outside of the song control system. Behav. Brain Res. 155, 307-318.

Roberts, J.L., Dutlow, C.M., Jakubowski, M., Blum, M., Millar, R.P., 1989. Estradiol stimulated preoptic area anterior hypothalamic pro-GnRH-GAP gene expression in ovariectomized rats. Mol. Endocrinol. 6, 127-134.

Robinson, J.E., Follett, B.K., 1982. Photoperiodism in Japanese quail: the termination of seasonal breeding by photorefractoriness. Proc. Roy. Soc. B 215, 95-116.

Roch, G.J., Busby, E.R., Sherwood, N.M., 2011. Evolution of GnRH: diving deeper. Gen. Comp. Endocrinol. 171, 1-16.

Rubin, B.S., King, J.C., 1994. The number and distribution of detectable luteinizing hormone releasing hormone cell bodies changes in association with the preovulatory LH surge in the brains of young but not middle-aged female rats. Endocrinology 134, 467-474.

Schally, A.V., Arimura, A., Kastin, A.J., Matsuo, H., Baba, Y., Redding, T.W., Nair, R.M.G., Debeljuk, L., White, W.F., 1971. Gonadotropin-releasing hormone: one polypeptide regulates secretion of luteinizing and follicle-stimulating hormones. Science 173, 1036-1038.

Seminara, S.B., Messager, S., Chatzidaki, E.E., Thresher, R.R., Acierno Jr., J.S., 2003. The GPR54 gene as a regulator of puberty. N. Engl. J. Med. 349, 1614-1627.

Silver, R., 1978. Parental behavior in ring does. Am. Sci. 66, 209-215.

Silverman, A.J., Livne, I., Witkin, J.W., 1994. The gonadotropin-releasing hormone neuronal systems: immunocytochemistry and in situ hybridization. In: Neill, J.D. (Ed.), Knobil and Neill's Physiology of Reproduction, second ed. Raven Press, New York, NY.

Simonneaux, V., Ansel, L., Revel, F.G., Klosen, P., Pevet, P., Mikkelsen, J.D., 2009. Kisspeptin and the seasonal control of reproduction in hamsters. Peptides 30, $146-153$.

Small, T.W., Sharp, P.J., Deviche, P., 2007. Environmental regulation of the reproductive system in a flexibly breeding Sonoran Desert bird, the rufous winged sparrow. Horm. Behav. 51, 483-495.

Small, T.W., Sharp, P.J., Bentley, G.E., Millar, R.P., Tsutsui, K., Mura, E., Deviche, P., 2008. Photoperiod-independent hypothalamic regulation of luteinzing hrmone secretion in a free-living Sonoran desert bird, the rufous-winged sparrow (Aimophila carpolis). Brain Behav. Evol. 71, 127-142.

Smith, J.T., Clay, C.M., Caraty, A., Clarke, I.J., 2007. KiSS-1 messenger ribonucleic acid expression in the hypothalamus of the ewe is regulated by sex steroids and season. Endocrinology 148, 1150-1157.

Smith, J.T., Coolen, L.M., Kriegsfeld, L.J., Sari, I.P., Jaafarzadeh-shirazi, M.R., Maltby, M., Bateman, K., Goodman, R.L., Tilbrook, A.J., Ubuka, T., Bentley, G.E., Clarke, I.J., Lehman, M.N., 2008. Variation in kisspeptin and RFamide-related peptide expression and terminal connections to gonadotropin releasing hormone neurons in the brain: a novel medium for seasonal breeding in the sheep. Endocrinology 149, 5770-5782.

Smith, J.T., Shahab, M., Pereira, A., Pau, K.Y., Clarke, I.J., 2010. Hypothalamic expression of KiSS1 and gonadotropin inhibitory hormone genes during the menstrual cycle of a non-human primate. Biol. Reprod. 83, 568-577.

Somoza, G.M., Miranda, L.A., Strobl-Mazzulla, P., Guilgur, L.G., 2002. Gonadotropinreleasing hormone $(\mathrm{GnRH})$ : from fish to mammalian brains. Cell Mol. Neurobiol. 22, 589-609.

Stevenson, T.J., Ball, G.F., 2009. Anatomical localization of the effects of reproductive state, castration, and social milieu on cells immunoreactive for gonadotropinreleasing hormone-I in male European starlings (Sturnus vulgaris). J. Comp. Neurol. 517, 146-155.

Stevenson, T.J., Ball, G.F., 2011. Information theory and the neuropeptidergic regulation of seasonal reproduction in mammals and birds. Proc. Roy. Soc. B 278, 2477-2485. 
Stevenson, T.J., MacDougall-Shackleton, S.A., 2005. Season- and age-related variation in neural GnRH1 and GnRH12 immunoreactivity in house sparrows. Gen. Comp. Endocrinol. 143, 33-39.

Stevenson, T.J., Bentley, G.E., Ubuka, T., Arckens, L., Hampson, E., MacDougallShackleton, S.A. 2008. Effects of social cues on GnRH1, GnRH12 and reproductive physiology in female house sparrows. Gen. Comp. Endocrinol. 156, 385-394.

Stevenson, T.J., Lynch, K.S., Lamba, P., Ball, G.F., Bernard, D.J., 2009a. Cloning of gonadotropin-releasing hormone I complementary DNAs in songbirds facilitates dissection of mechanisms mediating seasonal changes in reproduction. Endocrinology 150, 1826-1833.

Stevenson, T.J., Bernard, D.J., Ball, G.F., 2009b. Photoperiodic condition is associated with region-specific expression of GNRH1 mRNA in the preoptic area of the male starling (Sturnus vulgaris). Biol. Reprod. 81, 674-680.

Stevenson, T.J., Hahn, T.P., Ball, G.F., 2012. Variation in gonadotropin releasinghormone-1 gene expression in the preoptic area predicts transitions in seasonal reproductive state. J. Neuroendocrinol. 24, 267-274.

Stevenson, T.J., Small, T.W., Ball, G.F., Moore, I.T., 2012. Variation in the gonadotropin-releasing hormone 1 and the song control system in the tropical breeding rufous-collared sparrow is dependent on sex and reproductive state. Gen. Comp. Endocrinol. 178, 1-7.

Storey, C.R., Nicholls, T.J., 1976. Some effects of manipulation of daily photoperiod on the rate of onset of a photorefractory state in canaries. Gen. Comp. Endocrinol. 30, 204-208.

Strobl, F.J., Luderer, U., Besecke, L., Wolfe, A., Schwartz, N.B., Levine, J.E., 1993. Differential gonadotropin responses to N-methyl-D, L aspartate in intact and castrated male rats. Biol. Reprod. 48, 867-873.

Taziaux, M., Cornil, C.A., Dejace, C., Arckens, L., Ball, G.F., Balthazart, J., 2006. Neuroanatomical specificity in the expression of the immediate early gene c-fos following expression of appetitive and consummatory male sexual behavior in Japanese quail. Eur. J. Neurosci. 23, 1869-1887.

Theodosis, D.T., Poulain, D.A., 1992. Neuronal-glial and synaptic plasticity of the adult oxytocinergic system. Factors and consequences. Ann. N.Y. Acad. Sci. 12, 303-325.

Tilbrook, A.J., Clarke, I.J., 2001. Negative feedback regulation of the secretion and actions of gonadotropin releasing hormone in males. Biol. Reprod. 64, 735-742.

Tramontin, A.D., Brenowitz, E.A., 2000. Seasonal plasticity in the adult brain. Trends Neurosci. 23, 251-258.

True, C., Grove, K.L., Smith, M.S., 2011. Beyond leptin: emerging candidates for the integration of metabolic and reproductive function during negative energy balance. Front. Endocrinol. 2, 1-12.

Tsutsui, K., Ubuka, T., Bentley, G.E., Kriegsfeld, L.J., 2012. Gonadotropin-inhibitory hormone (GnIH): Discovery, progress and prospect. Gen. Comp. Endocrinol. 177, 305-314.

Ubuka, T., Bentley, G.E., 2009. Identification, localization, and regulation of passerine GnRH1 messenger RNA. J. Endocrinol. 201, 81-87.

Ubuka, T., Cadigan, P.A., Wang, A., Liu, J., Bentley, G.E., 2009. Identification of European starling GnRH1 precursor mRNA and its seasonal regulation. Gen. Comp. Endocrinol. 162, 301-306.

Urbanski, H.F., 1990. A role for N-methyl-D-aspartate receptors in the control of seasonal breeding. Endocrinology 127, 2223-2228.

Warren, W.C., Clayton, D.F., Ellegren, H., Arnold, A.P., Hillier, L.W., Künstner, A., Searle, S., White, S., Vilella, A.J., Fairley, S., Heger, A., Kong, L., Ponting, C.P., Jarvis, E.D., Mello, C.V., Minx, P., Lovell, P., Velho, T.A., Ferris, M., Balakrishnan, C.N., Sinha, S., Blatti, C., London, S.E., Li, Y., Lin, Y.C., George, J., Sweedler, J., Southey, B., Gunaratne, P., Watson, M., Nam, K., Backström, N., Smeds, L., Nabholz, B.,
Itoh, Y., Whitney, O., Pfenning, A.R., Howard, J., Völker, M., Skinner, B.M., Griffin, D.K., Ye, L., McLaren, W.M., Flicek, P., Quesada, V., Velasco, G., Lopez-Otin, C., Puente, X.S., Olender, T., Lancet, D., Smit, A.F., Hubley, R., Konkel, M.K., Walker, J.A., Batzer, M.A., Gu, W., Pollock, D.D., Chen, L., Cheng, Z., Eichler, E.E., Stapley, J., Slate, J., Ekblom, R., Birkhead, T., Burke, T., Burt, D., Scharff, C., Adam, I., Richard, H., Sultan, M., Soldatov, A., Lehrach, H., Edwards, S.V., Yang, S.P., Li, X., Graves, T., Fulton, L., Nelson, J., Chinwalla, A., Hou, S., Mardis, E.R., Wilson, R.K., 2010. The genome of a songbird. Nature 464, 757-762.

White, S.A., Fernald, R.D., 1993. Gonadotropin-releasing hormone-containing neurons change size with reproductive state in female haplochromis burtoni. J. Neurosci. 12, 434-441.

White, S.A., Nguyen, T., Fernald, R.D., 2002. Social regulation of gonadotropinreleasing hormone. J. Exp. Biol. 205, 2567-2581.

Wiemann, J.N., Clifton, D.K., Steiner, R.A., 1990. Gonadotropin releasing hormone messenger ribonucleic acid levels are unaltered with changes in the gonadal hormone milieu of the adult male rat. Endorinology 127, 523-532.

Wilczynski, W., Allison, J.D., Marler, C.A., 1993. Sensory pathways linking social and environmental cues to endocrine control regions of amphibian forebrains. Brain Behav. Evol. 42, 252-264.

Wilson, F.E., Donham, R.S., 1988. Daylength and control ofseasonal reproduction in male birds. In: Stetson, M.H. (Ed.), Processing of Environmental Information in Vertebrates. Springer, Berlin, Germany, pp. 101-120.

Wingfield, J.C., 1988. Changes in reproductive function of free-living birds in direct response to environmental perturbations. In: Stetson, M.H. (Ed.), Proceedings of Environmental Information in Vertebrates. Springer, Berlin, Germany, pp. 121148.

Wingfield, J.C., Kenagy, G.J., 1991. Natural regulation of reproductive cycles. In: Schreibman, M., Jones, R.E. (Eds.), Vertebrate Endocrinology: Fundamentals and Biomedical Implications. Academic Press, New York, USA, pp. 181-241.

Wingfield, J.C., Hahn, T.P., Levin, R., Honey, P., 1992. Environmental predictability and control of gonadal cycles in birds. J. Exp. Zool. 261, 214-231.

Wintermantel, T.M., Campbell, R.E., Porteous, R., Bock, D., Grone, H.J., Todman, M.G. Korach, K.S., Greiner, E., Perez, C.A., Schutz, G., Herbison, A.E., 2006. Definition of estrogen receptor pathway critical for estrogen positive feedback to gonadotropin releasing hormone neurons and fertility. Neuron 52, 271280.

Wolfe, A.M., Wray, S., Westphal, H., Radovick, S., 1996. Cell-specific expression of the human gonadotropin-releasing hormone gene in transgenic animals. J. Biol. Chem. 271, 20018-20023.

Wray, S., Hoffman, G., 1986. Postnatal morphological changes in rat LHRH neurons correlated with sexual maturity. Neuroendocrinology 43, 93-97.

Xu, J., Mirigiti, M.A., Cowley, M.A., Grove, K.L., Smith, M.S., 2009. Gonadotropin releasing hormone neuronal activity during lactation: role of inhibitory effects of neuropeptide Y. Endocrinology 150, 333-340.

Yamamura, T., Hirunagi, K., Ebihara, S., Yoshimura, T., 2004. Seasonal morphological changes in the neuro-glial interaction between gonadotropin-releasing hormone nerve terminals and glial endfeet in Japanese quail. Endocrinology $145,4264-4267$.

Zhao, S., Kelm, R.J., Fernald, R.D., 2010. Regulation of gonadotropin-releasing hormone 1 gene transcription by members of the purine-rich element binding protein family. Am. J. Physiol. Endocrinol. Metab. 298, E524-E533.

Zoeller, R.T., Young, W.S., 1988. Changes in cellular levels of messenger ribonucleic acid encoding gonadotropin releasing hormone in the anterior hypothalamus of female rats during the estrous cycle. Endocrinology 123, 1688-1699.

Zohar, Y., Munoz-Cueto, J.A., Elizur, A., Kah, O., 2010. Neuroendocrinology of reproduction in teleost fish. Gen. Comp. Endocrinol. 165, 438-455. 